\title{
Petrologic modeling of chloritoid-glaucophane schists from the NW Iberian Massif
}

\author{
A. López-Carmona ${ }^{\mathrm{a}, \mathrm{b}, *}, \mathrm{~J}$. Abati ${ }^{\mathrm{a}, \mathrm{b}}$, J. Reche $^{\mathrm{c}}$ \\ a Departamento de Petrologia y Geoquímica, Universidad Complutense de Madrid, 28040 Madrid, Spain \\ - Instituto de Geología Económica-Consejo Superior de Investigaciones Científicas, 28040 Madrid, Spain \\ ${ }^{c}$ Unitat de Petrología i Geoquímica, Facultat de Ciències, Universitat Autònoma de Barcelona, 08193 Bellaterra (Barcelona), Spain
}

Keywords:

Malpica-Tui unit

High-pressure terranes

Blueschist

Glaucophane-chloritoid

$P-T$ pseudosection

\begin{abstract}
A B S T R A C T
Two P-T pseudosections computed with Thermocalc and Perplex software for high-pressure pelitic Ceân Schists from the NW Iberian Massif show that the paragenesis chloritoid + glaucophane, preserved as relict micro-inclusions in garnet porphyroblasts, is stable above $17-18 \mathrm{kbar}$, indicating a first stage of subduction with $65-70 \mathrm{~km}$ of burial. The subsequent growth of biotite and albite porphyroblasts, according to their stability fields in a MnNCKFMASH $P-T$ phase diagram, indicates strong decompression accompanied by slight heating to reach a metamorphic peak at $\sim 500^{\circ} \mathrm{C}$. This mineral association, described in many subduction-related terranes around the world as one of the high-pressure indicators for metapelites, has not been reported previously in the NW Iberian Massif. The schists contains an initial high-pressure assemblage formed by chloritoid+garnet $\left(\begin{array}{llll}\mathrm{Alm}_{0.58} & \mathrm{PrpO}_{0.03} & \mathrm{Grs}_{0.38} & \mathrm{Sps}_{0.09}\end{array}\right) \pm$ glaucophane + phengite (3.5-3.4Sip.f.u.) + paragonite + chlorite + epidote + rutile + ilmenite + quartz, preserved as micro-inclusions in garnet, chloritoid and albite porphyroblasts defining an $S_{1}$ internal fabric. The matrix foliation $\left(S_{2}\right)$ additionally contains a high-pressure association formed by garnet $\left(\operatorname{Alm}_{0.68} \operatorname{Prp}_{0.04} \mathrm{Grs}_{0.25} \mathrm{Sps}_{0.03}\right)+$ phengite (3.4-3.3Si p.f.u.) + paragonite + winchite + barroisite + hornblende + chloritoid + chlorite + epidote + rutile + ilmenite + albite + quartz \pm biotite. An initial pseudosection calculated in the KFMASH system with Thermocalc 3.26 gives pressure estimates through Si-content in phengite barometry that are in agreement with conventional thermobarometry and Thermocalc average $P-T$ calculations, but is unable to describe the full complexity of the mineral assemblages of the schists. For this reason, a more complete $P-T$ pseudosection in the model system MnNCKFMASH was calculated with Perplex 07. This provides a reliable succession of mineral assemblages that are consistent with the petrographic observations and allows a mineralogical sequence to be set for each metamorphic event in the $P-T$ evolution of the high- $P$ pelitic Ceán Schists.
\end{abstract}

\section{Introduction}

High-pressure (high- $P$ ) and low-temperature (low-T) rocks in orogenic belts constitute the main markers of paleo-subduction zones, and knowledge of their $P-T$ conditions can provide useful information about the mechanisms of subduction and the maximum burial reached (e.g. Ernst, 1973; Platt, 1993; Maruyama et al., 1996; Ernst, 2001; Babist et al., 2006; Warren and Miller, 2007; Warren et al., 2008; Masago et al., 2009; Omori et al., 2009; Santosh et al., 2009).

Data about the metamorphic evolution of subducted terranes obtained through petrologic modeling are at the core of geodynamic models and paleogeographic reconstructions of the lithospheric plates. These models, and the plate relationships and paleogeography

\footnotetext{
* Corresponding author. Departamento de Petrología y Geoquímica, Facultad de Ciencias Geológicas, C/Jose Antonio Novais, 2, 28040 Madrid, Spain. Tel.: + 34913944903 ; fax: + 34 915442535 .

E-mail addresses: alcarmona@geo.ucm.es (A. López-Carmona), abati@geo.ucm.es (J. Abati), Joan.Reche@uab.cat (J. Reche).
}

of the Paleozoic, are the key to unraveling the evolution of the periGondwanan terranes during the Variscan orogeny. In this context, the northwestern section of the Iberian Massif offers an important clue to understanding the evolution of the European Variscan belt. A key aspect of this section is the presence of exotic terranes emplaced as large, complex alloch thonous sheets upon sequences deposited on the passive margin of northern Gondwana (Martínez Catalán et al., 2007). The different exotic units can be grouped into three main terranes. The upper terrane is viewed as a piece of an island arc developed at $c a$. $500 \mathrm{Ma}$ in an active part of the northern Gondwana margin, the related back-arc extension of which probably helped to open the Rheic Ocean. This arc was subsequently accreted to Laurentia or Baltica between 440 and $410 \mathrm{Ma}$ (age of the high-pressure metamorphism; Fernández-Suárez et al., 2007). The intermediate terrane includes two associated ophiolitic units that are considered to be remnants of the Rheic Ocean accreted below the upper units at ca. $385 \mathrm{Ma}$. Finally, in the lower structural position, the Basal Units are interpreted to represent a large, complex sheet emplaced upon sequences deposited on the most external passive margin of northern 
Gondwana (Martínez Catalán et al., 2009). The Basal Units show the imprints of a late Devonian high- $P$ metamorphism that has been interpreted to be related to its subduction beneath the southern margin of Laurussia at the onset of Variscan convergence (Arenas et al., 1995; Martínez Catalán, et al., 1996; Arenas, et al., 1997). In this study, we use the thermodynamic modeling software Thermocalc (Powell and Holland, 1988) and Perplex (Connolly, 2005) to constrain the metamorphic evolution of chloritoid-glaucophane pelitic schists from the high-P Malpica-Tui Unit in Galicia (NW Spain). This unit is the westernmost exposure of the Basal Units of the Allochthonous Complexes of the NW Iberian Massif. The high-P pelitic schists (Ceán schists, Fig. 1) crop out in the northern coastal section of the MalpicaTui Unit and contain an initial chloritoid-glaucophane paragenesis, which is one of the high pressure indicators for metapelites that has been reported in several high-P terranes around the world (e.g. Île de Groix, Kiénast and Triboulet, 1972; the Kaczawa Complex, Kryza et al.,
1990; the Peloponnese, Katagas, 1980; Theye et al., 1992; the Gran Paradiso Massif, Chopin, 1981; north Qilian Orogen, Song et al., 2007, Wei and Song, 2008; Oman, El-Shazly and Liou, 1991, Warren and Waters, 2006). The geological significance that can be inferred from the presence of glaucophane has been considered by several authors to explain Siluro-Devonian subduction and collision processes in the majority of the geotectonic models proposed for the Variscan orogen (Behr et al., 1984; Matte, 1986; Pin and Vielzeulf, 1988).

The presence of rocks with comparable mineral associations is common in many of the European Variscan outcrops. Hence, the Basal Units of the NW Iberian Massif can be correlated with similar terranes with high- $P$ and low- to intermediate-temperature metamorphism from Portugal to the northern areas of eastern Europe, such as the Kaczawa Complex in the Polish Sudetes of the Bohemian Massif (Kryza et al., 1990; Cymerman et al., 1997). In addition, similarities between certain geological units of the Armorican Massif (Brittany)

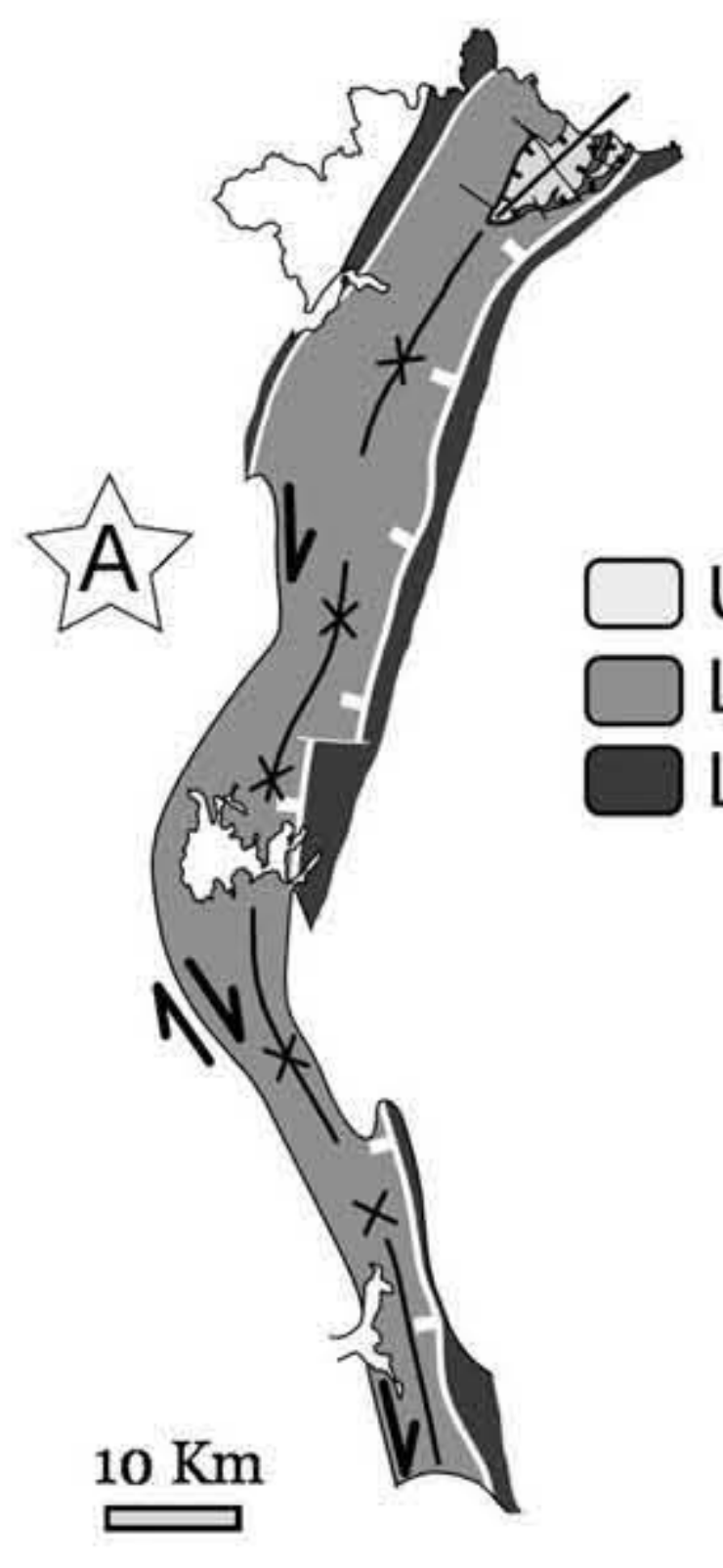

\section{UPPER SLICE \\ LOWER SLICE \\ LOWER ALLOCHTHON}

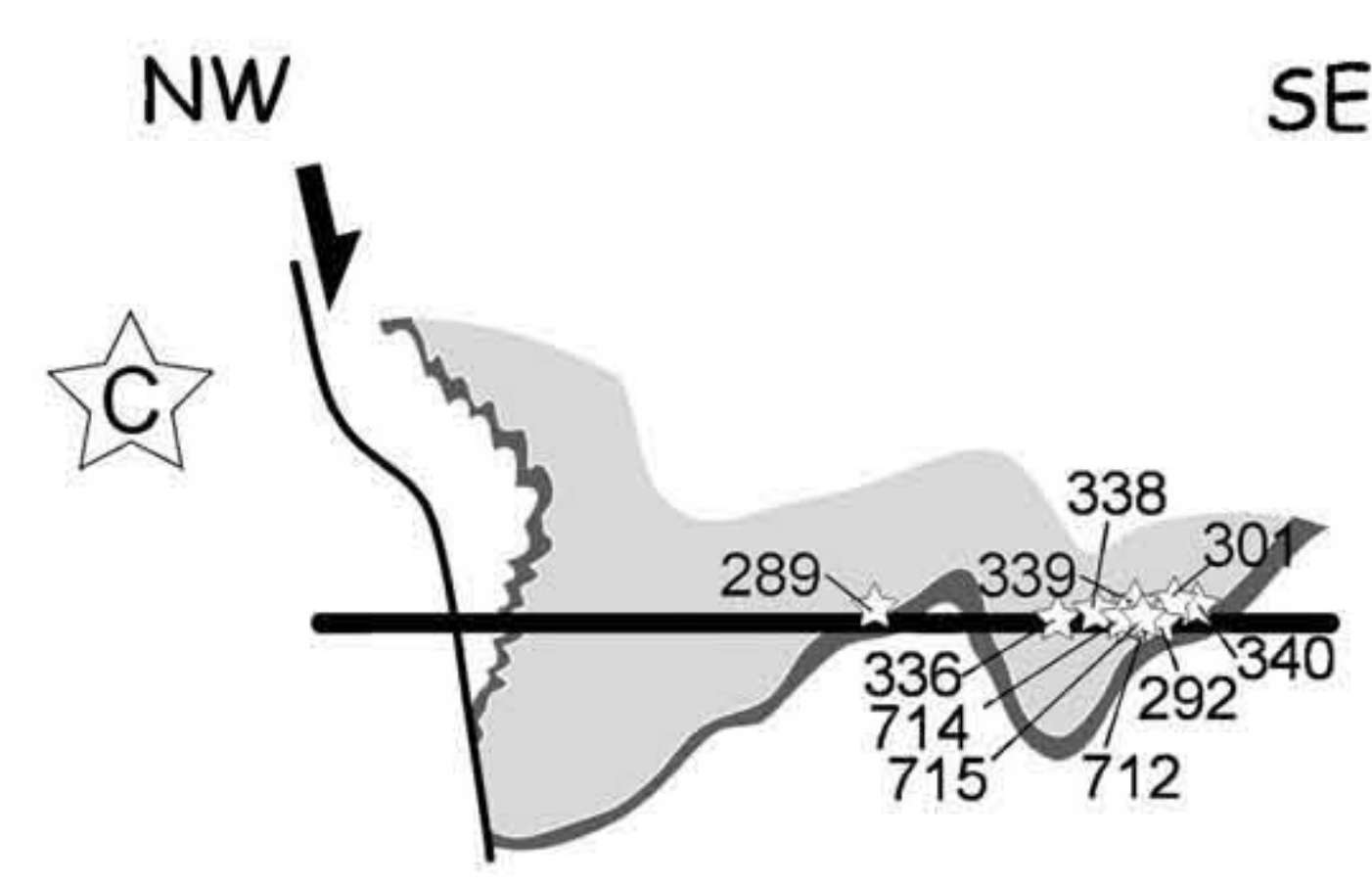

PAZOS SYNFORM

\section{Ceán Schists}

Cambre Amphibolites

Felsic Orthogneisses

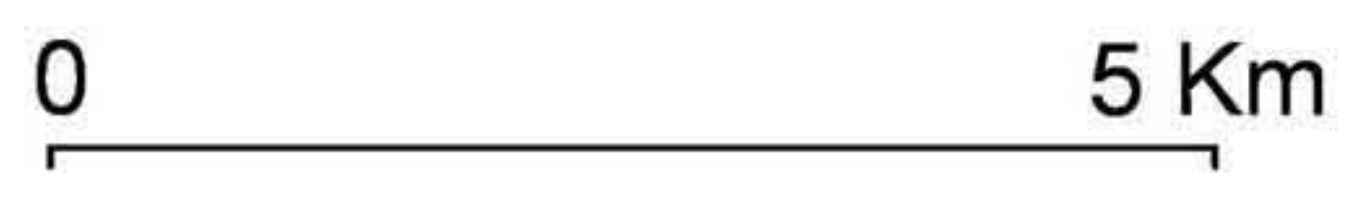

SE
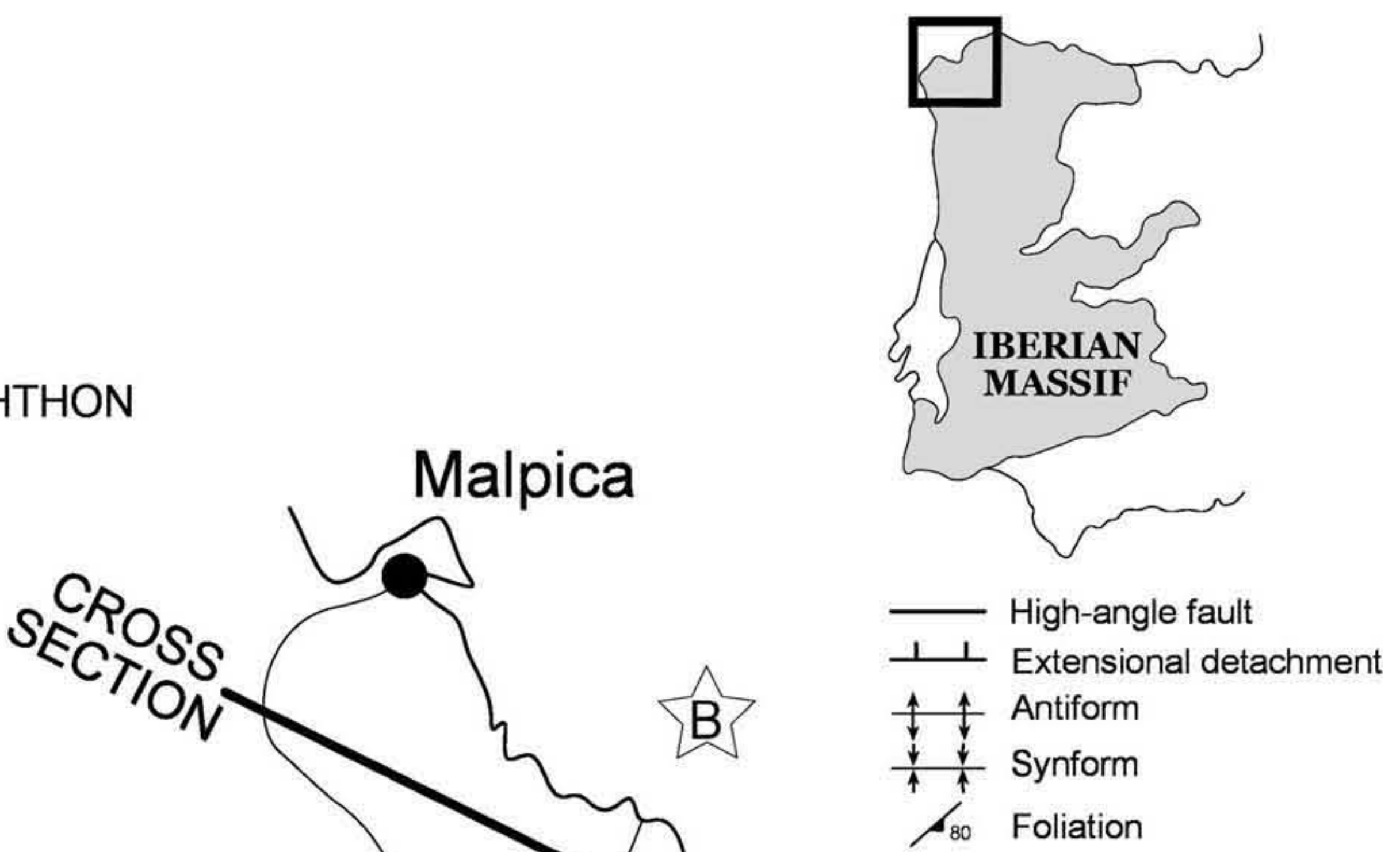

\section{E}

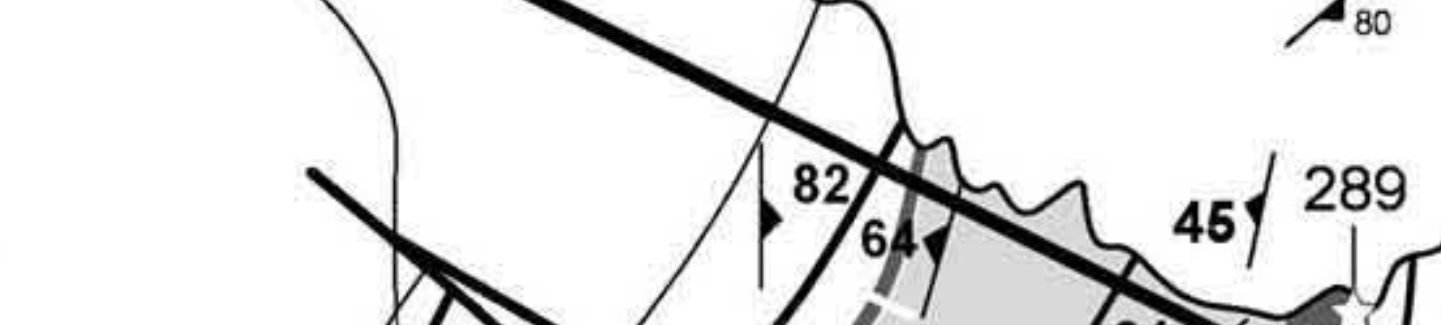

289 
and the Malpica-Tui Unit allows correlation of the latter with the Île de Groix (Kiénast and Triboulet, 1972; Shelley and Bossière, 1999; Ballevre et al., 2003) and Champtoceaux Complex (Ballèvre et al., 2009 ), particularly since the age of the high- $P$ metamorphism is the same in both terranes (Bosse et al., 2005). This age has been tightly constrained to around $371 \mathrm{Ma}$ in NW Iberia by ${ }^{40} \mathrm{Ar} /{ }^{39} \mathrm{Ar}$ geochronology on white micas from different lithologies, including eclogites (Van Calsteren et al., 1979; Rodríguez et al., 2003), and by U-Pb zircon ages (Abati et al., 2009).

However, chloritoid-glaucophane mineral assemblages has not been previously described in the NW Iberian Massif. Hence, one of the goals of this study is to record the presence of choritoid-glaucophane pelitic schists and document their petrological characteristics and metamorphic $P-T$ conditions.

\section{Geological setting}

The Malpica-Tui Unit is the westernmost exposure of the Basal Units in the Allochthonous Complexes of NW Iberia. It crops out as an elongated synformal structure oriented $\mathrm{N}-\mathrm{S}$, the axis of which plunges slightly to the north. It is about $150 \mathrm{~km}$ long and $10 \mathrm{~km}$ wide, stretching from Malpica in A Coruña, to Tui in Pontevedra (Fig. 1). To the east, it is bordered by a basal shear zone that overlies the Schistose Domain of the Galicia Trás-os-Montes Zone (Gil Ibarguchi and Ortega Gironés, 1985; Llana-Fúnez and Marcos, 2002). To the west, is bordered by a subvertical dextral strike-slip fault known as the Malpica-Lamego shear zone (Coke and Ribeiro, 2000; Llana-Fúnez, 2001).

The Ceán schists outcrop in the coastal strip of the Malpica-Tui Unit, in the core of the north-plunging, late Variscan Pazos synform (Alonso and González, 1982), and so occupies the highest structural level of the unit (Fig. 1). The unit is entirely composed of rocks belonging to the Ceán-Razo Series (Ortega, 1980), which consists of: (1) a sequence of massive finely foliated amphibolites with lawsonite-pseudomorphs and variable thickness that define the cartographic limit of the structure, and (2) a thicker metasedimentary sequence consisting of pelitic schists (Ceán Schists) and minor intercalations of ampelites, lydites and carbonates. The transition between the two lithologies is gradual (Arps, 1981) (Fig. 2), and locally there are horizons where both are interbedded. This volcanosedimentary sequence shows a metamorphic evolution developed almost entirely under blueschist facies conditions, whereas the rest of the Malpica-Tui Unit records the existence of metamorphism developed in eclogites facies conditions. Therefore, two lithologic assemblages with different tectonothermal evolution can be differentiated; a structurally lower assemblage consisting of metasediments and granitic to granodioritic orthogneisses with abundant mafic enclaves, and an upper assemblage composed of amphibolites with lawsonite pseudomorphs and pelitic schists (Fig. 1).

Peak conditions of metamorphism in the lower assemblage were approximately $P=25 \mathrm{kbar}$ and $T=610^{\circ} \mathrm{C}$ (Rodríguez Aller, 2005), whereas in the upper assemblage metamorphism is of lower grade, with an initial blueschist facies event highly overprinted by epidoteamphibolite and greenschist facies metamorphism. This gap in the $P-T$ conditions of metamorphism, together with the telescoping of isograds, are compatible with an extensional detachment separating the two slices (López-Carmona et al., 2008).

The geochemistry of the mafic rocks is also different in the two assemblages, with continental alkali basalts in the lower slice and $\mathrm{N}$-MORB basalts in the upper slice. The lithologic association and geochemistry of the lower slice is clearly of continental affinity, whereas the upper slice represents a volcanosedimentary sequence that is viewed as representing the more distal, extremely extended part of the same continental margin, transitional to an oceanic domain (Rodríguez Aller, 2005).

\section{Petrography and field occurrence}

The Ceán Schists have a composition of typical pelites (Fig. 8; Table 4) (e.g. Atherton and Brotherton, 1982), showing a mediumgrained porphyro-lepidoblastic texture and a highly developed planar to plano-linear fabric. The deformation is generally strong and, in discrete areas, the regional foliation is transitional to mylonitic types, with the development of subgrains and quartz ribbons around the porphyroblasts, and marked undular extinction of quartz and white micas. Late $C$ shear bands and kink-band structures are also common (Fig. 2).

The blueschist facies mineral assemblage is formed by Grt $+\mathrm{Phn}+$ $\mathrm{Pg} \pm \mathrm{Gln}+\mathrm{Ctd}+\mathrm{Chl}+\mathrm{Ep}+\mathrm{Rt}-\mathrm{Ilm}+\mathrm{Qtz}$ (mineral abbreviations are after Kretz, 1983; Holland and Powell, 1998). These minerals occur preserved as micro-inclusions in garnet and chloritoid porphyroblasts, and define an internal fabric $\left(S_{1}\right)$ that frequently shows cross-cutting relationships with the external foliation $\left(S_{2}\right)$ (Fig. 3). The matrix foliation $\left(\mathrm{S}_{2}\right)$ is formed by the mineral association $\mathrm{Grt}+\mathrm{Phn}+\mathrm{Pg} \pm \mathrm{Win} \pm$ $\mathrm{Bar} \pm \mathrm{Hb}-\mathrm{Ts}+\mathrm{Ctd}+\mathrm{Chl}+\mathrm{Ep}+\mathrm{Rt}-\mathrm{Ilm}+\mathrm{Ap}+\mathrm{Tur}+\mathrm{Qtz} \pm \mathrm{Bt} \pm \mathrm{Ab}$ (Fig. 3), which probably represents an evolution of the $S_{1}$ assemblage to slightly higher temperature and lower pressures, but still within blueschist facies. Post- $\mathrm{S}_{2}$ deformations include the restricted development of spaced ' $C$ ' shear bands, tight and straight $\mathrm{D}_{3}$ folds, and a later gentle subhorizontal crenulation. The occurrence of retrograde minerals, such as chlorite, sericite, stilpnomelane, carbonates and sulfurs and sphene, in the $C$ planes indicates very low-grade greenschist facies conditions.

The presence of garnet and phengite in the absence of biotite is typical of pelites in high- $P$ belts (Kurata and Banno, 1974; Răheim, 1977; Hynes and Forest, 1988; Arenas et al., 1995). In the Ceán Schists, biotite is absent in the $S_{1}$ micro-inclusions fabric, but is a common mineral in some of the samples. It tends to grow as orientated lepidoblasts in the matrix foliation, and as a late $S_{2}$ mineral, essentially replacing garnet and white mica. Petrographic observation suggests that biotite grew partly as a stable $S_{2}$ mineral in favorable compositional types (Fig. 3). Glaucophane has not been identified in the matrix of the schists, but in some samples accessory amounts of sodic-calcic and calcic amphiboles occur, probably after glaucophane. They include bluish-green winchite and barroisite, and smaller amounts of green homblende and tschermakite. Sodic-calcic amphiboles are typically developed during exhumation of high- $P$ rocks at the expense of peak phases (e.g. Hirajima and Compagnoni, 1993).

From the bottom to the top of the sequence, the schists show a marked variation in mineralogy and texture. In the basal part, they are interbedded with the lawsonite-pseudomorph amphibolites (samples $336,338,339,340,289,292,301,712,714$, and 715 ), and the most complete and best preserved blueschist facies parageneses are found here (referred to hereafter as the "lower schists"). Locally, a pervasive growth of late albite porphyroblasts occurs, either defining a parallel banding (sample F-03) or without orientation (and F-04), and with a random distribution that can be related to compositional differences in the sedimentary protolith (Alonso and González, 1982; Gil Ibarguchi and Ortega Gironés, 1985). Upwards in the sequence the content of mica decreases, garnet disappears, and a gradual increase of opaque phases and quartzite beds occur (samples F-07 and F-08). The paragenesis becomes restricted to fine-grained white mica $+\mathrm{Chl}+$ Qtz, giving this rock a slaty texture in the upper part of the sequence (referred to hereafter as the "upper schists") and suggesting that the metamorphic gradient decreases rapidly upwards (Fig. 2). The transition occurs at approximately $500 \mathrm{~m}$ from the base of the sequence, indicating important telescoping of metamorphic isograds compatible with extensional detachment faulting (López-Carmona et al., 2008).

The most abundant porphyroblasts are garnets. According to their textural and chemical characteristics, these can be divided into two different types: texturally zoned garnets with inclusion-rich cores and 

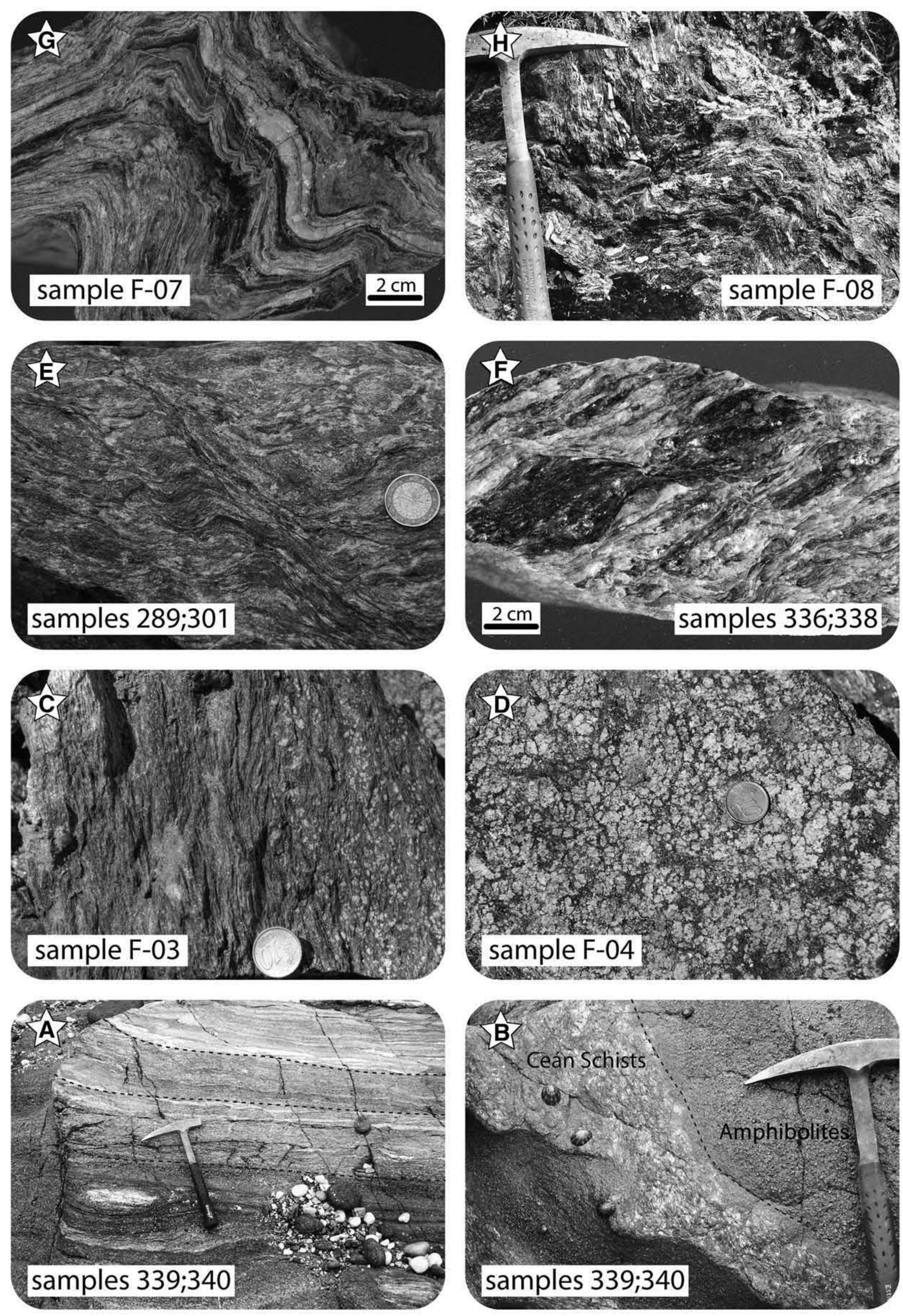

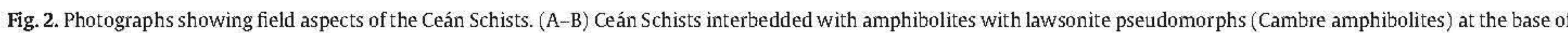

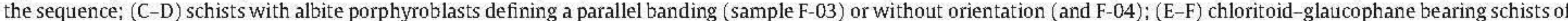

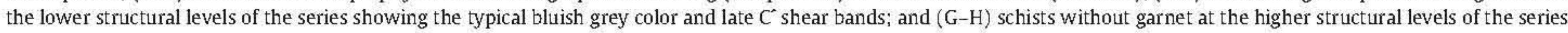
showing the gradual increase of opaque phases and quartzite beds. 
rims of variable thickness with fewer inclusions (type I garnets), and smaller, homogeneous garnets scattered in the matrix and commonly included in albite porphyroblasts (type II garnets). Both types of garnet can occur in the same rock. The type I garnets are coarse grained $(4-7 \mathrm{~mm})$ and sub- to idiomorphic. Their central areas are also idiomorphic and the identified micro-inclusions are of $\mathrm{Gln}, \mathrm{Ctd}$, Chl, Phn-Pg, Rt-Ilm and Qtz. The core-rim texture suggests two stages of growth. The external zone is synkinematic with respect to the $S_{2}$ fabric. In detail, some differences in the chemical composition of type I garnet can be observed depending on the structural position of the samples. In the lower structural levels of the series, type I garnets appear as inclusions in chloritoid porphyroblasts, reaching a maximum size of $0.10-0.20 \mathrm{~mm}$. Type II garnets are generally smaller (1$4 \mathrm{~mm}$ in diameter) and idiomorphic. They show simple textures containing only a few inclusions that tend to concentrate in the cores. They usually form bands parallel to $S_{2}$, scattered in the white micarich levels, or as inclusions in albite porphyroblasts no larger than $0.20-0.30 \mathrm{~mm}$ (Fig. 3). If inclusions are present, they consist of fine rutile needles (frequently partially replaced by ilmenite), acicular chlorite aggregates, small prismatic epidote crystals, polycrystalline quartz aggregates and rare apatite. Samples containing type I garnets with glaucophane inclusions crop out in the lower structural levels of the sequence, interbedded with the lawsonite-pseudomorph amphibolites. Hence, their mineral chemical composition reflects the maximum burial conditions.

As with the garnets, white mica, chloritoid, chlorite and epidote each occur in two textural types. Type I white micas are fine crystals with grain sizes ranging from 0.25 to $0.75 \mathrm{~mm}$ and define $S_{1}$ as inclusions in garnet and chloritoid porphyroblasts. Type II white micas are present as micro-inclusions in the late albite porphiroblasts and as $\mathrm{S}_{2}$ lepidoblasts in the matrix. Chloritoid appears as micro-inclusions in garnets (type I chloritoid) as an $\mathrm{S}_{1}$ mineral, and as coarse prisms with no core-rim zonation that reach more than $9 \mathrm{~mm}$ in length in the $S_{2}$ matrix foliation (type II chloritoids). It is not possible to determine whether the latter chloritoid is in equilibrium with the rest of the $\mathrm{M}_{2}$ phase or is a relict phase from the $\mathrm{M}_{1}$ stage. However, the petrographic features suggest that type II chloritoids were stable at least until the early $\mathrm{M}_{2}$ stage. Type I chlorites grains occur as micro-inclusions in garnet and albite porphyroblasts, whereas type II chlorites occur in the quartz-mica matrix domains, and in the pressure shadows of other porphyroblasts. Type I epidotes are acicular or prismatic crystals ( $<0.4 \mathrm{~mm}$ long) forming micro-inclusions in type II garnets, whereas type II epidotes are larger prismatic crystals $(>2 \mathrm{~mm})$ in the matrix. Apatite occurs as idiomorphic prisms of variable length up to $2 \mathrm{~mm}$, and rarely as small (0.5-1 mm long) prisms included in type II garnets. In some cases apatite contains rutile inclusions that define a straight schistosity, suggesting a metamorphic origin.

A summary of the petrographic data is shown in Fig. 4, in which the observed mineral associations have been grouped according to their relationship to the two metamorphic events, $\mathrm{M}_{1}$ and $\mathrm{M}_{2}$.

\section{Mineral chemistry}

Six representative samples of the Ceán Schists were analysed with a JEOL-Superprobe JXA-8900 M microprobe equipped with five spectrometers at the Luis Bru Electronic Microscopy Centre (Universidad Complutense de Madrid). The operating parameters were: $15 \mathrm{kV}$ accelerating voltage, $20 \mathrm{nA}$ beam current, between 1 and $5 \mu \mathrm{m}$ of beam diameter and $10 \mathrm{~s}$ counting time. The selected samples were the least retrograded with the best preserved parageneses. A selection of analyses is shown in Tables 1 and 2.

\subsection{Garnet}

Both type I and type II garnets are almandine (Table 3). Type I garnet profiles (Fig. 5) show, from core to rim: (1) a slight increase in pyrope and a more pronounced increase of almandine, (2) a compensating decrease in grossular and spessartine, and (3) a relatively constant $\mathrm{Fe} /(\mathrm{Fe}+\mathrm{Mg})$ ratio. The central plateau with maximum $X_{\mathrm{Ca}}$ and $\mathrm{X}_{\mathrm{Mn}}$ matches the idiomorphic core and represents a first stage of growth, in which grossular and spessartine reach a maximum, almandine shows the opposite trend, and pyrope remains almost constant.

As mentioned previously, some differences in type I garnet chemical composition occur with structural position. Type I garnets from the lower part are richer in $\mathrm{X}_{\mathrm{Ca}}$ and poorer in $\mathrm{X}_{\mathrm{Fe}}, \mathrm{X}_{\mathrm{Mg}}$ and $\mathrm{X}_{\mathrm{Mn}}$ with respect to those in the upper part of the series. The most marked difference is in the grossular content, which varies from $\sim 0.30$ to $\sim 0.15$ between the lower and upper part, suggesting significantly lower pressure at the upper levels, assuming a higher grossular content implies higher pressures (see Hollister, 1966; Atherton, 1968; Thompson et al., 1982; Chakraborty and Ganguly, 1991; Spear, 1995; Holdaway, 2001; Zuluaga et al., 2005).

Type II garnet chemical profiles (Fig. 5) show, from core to rim, a slightly increase in pyrope and almandine. Grossular and spesartine contents decrease significantly and the ratio $\mathrm{Fe} /(\mathrm{Fe}+\mathrm{Mg})$ remains almost constant, decreasing slightly towards the rims. At the same structural level, type I garnets rims and type II garnets cores have similar compositions, suggesting that they grew at the same time.

\subsection{Amphibole}

Three types of amphiboles can be distinguished. The blue amphibole that appears as micro-inclusions $(0.25-0.5 \mathrm{~mm})$ in type I garnets is a sodic amphibole with an Si content above 7.8 and a $\mathrm{Na}$ / $(\mathrm{Na}+\mathrm{Ca})$ ratio above 0.97 , which corresponds to glaucophane with a mean $\mathrm{X}_{\mathrm{Fe}}$ of $0.05\left[\mathrm{X}_{\mathrm{Fe}}=\mathrm{Fe}^{3+} /\left(\mathrm{Fe}^{3+}+\mathrm{Al}\right)\right]$. The matrix green-blue amphiboles belong to the sodic-calcic group, and comprise winchite and barroisite with $\mathrm{X}_{\mathrm{Mg}} \approx 0.48-0.63\left[\mathrm{X}_{\mathrm{Mg}}=\mathrm{Mg} /(\mathrm{Mg}+\mathrm{Fe})\right]$ and $\mathrm{X}_{\mathrm{Fe}} \approx 0.29$. Finally, the green amphiboles found in the matrix of the schists range in composition from $\mathrm{Mg}$-hornblende to Fe-hornblende and tschermakite, with $\mathrm{X}_{\mathrm{Mg}} \approx 0.49-0.62$ and $\mathrm{X}_{\mathrm{Fe}} \approx 0.07-0.22$.Their $\mathrm{Al}_{2} \mathrm{O}_{3}$ and $\mathrm{Na}_{2} \mathrm{O}$ contents are relatively high (Table 2 ), which is consistent with their coexistence at relatively high pressures with glaucophane (Reynard and Ballèvre, 1988; Smelik and Veblen, 1992).

\subsection{White Mica}

The composition of both types of micas (type I and type II) corresponds to either phengite or paragonite. The Si content of type I phengites lies in the range of 3.4-3.5 cations p.f.u. (on a basis of 11 oxygen), and the range of 3.3-3.4cationsp.f.u. for type II phengites (Tables 1 and 2). $\mathrm{X}_{\mathrm{Fe}}$ increases from 0.46 in type I to 0.48 in type II. The composition of type I and II paragonites, on the other hand, is relatively constant, with very low variation in $\mathrm{X}_{\mathrm{Fe}}$ and a high $\mathrm{Na} /(\mathrm{Na}+\mathrm{K})$ ratio $(0.97$ and 0.80 for type I and type II, respectively). In the diagram $\mathrm{FeO}_{\mathrm{T}}-\mathrm{Al}_{2} \mathrm{O}_{3}$ (Fig. 6), the majority of the white micas are classified as metamorphic micas from glaucophane schists (Miyashiro, 1973). Some of the analyses corresponding to type II white micas plot in the chlorite-biotitealmandine zone, suggesting that they grew under slightly different $P-T$ conditions (lower pressure and higher temperature). The six analyses that plot at the limit or within this field correspond to the biotite-bearing schists. Comparison of the phengite chemistry with other high- $P$ pelites of the Basal Units shows a marked similarity between the type II phengites from the Ceán Schists and the type I phengites from the Santiago Schists (Fig. 6), outcropping to the east in the Ordenes Complex. The phengites of the Santiago Schists are part of a high-pressure foliation preserved as inclusions in albite porphyroblasts, whereas the regional foliation is developed at medium pressure (Arenas et al., 1995). However, the high silica 

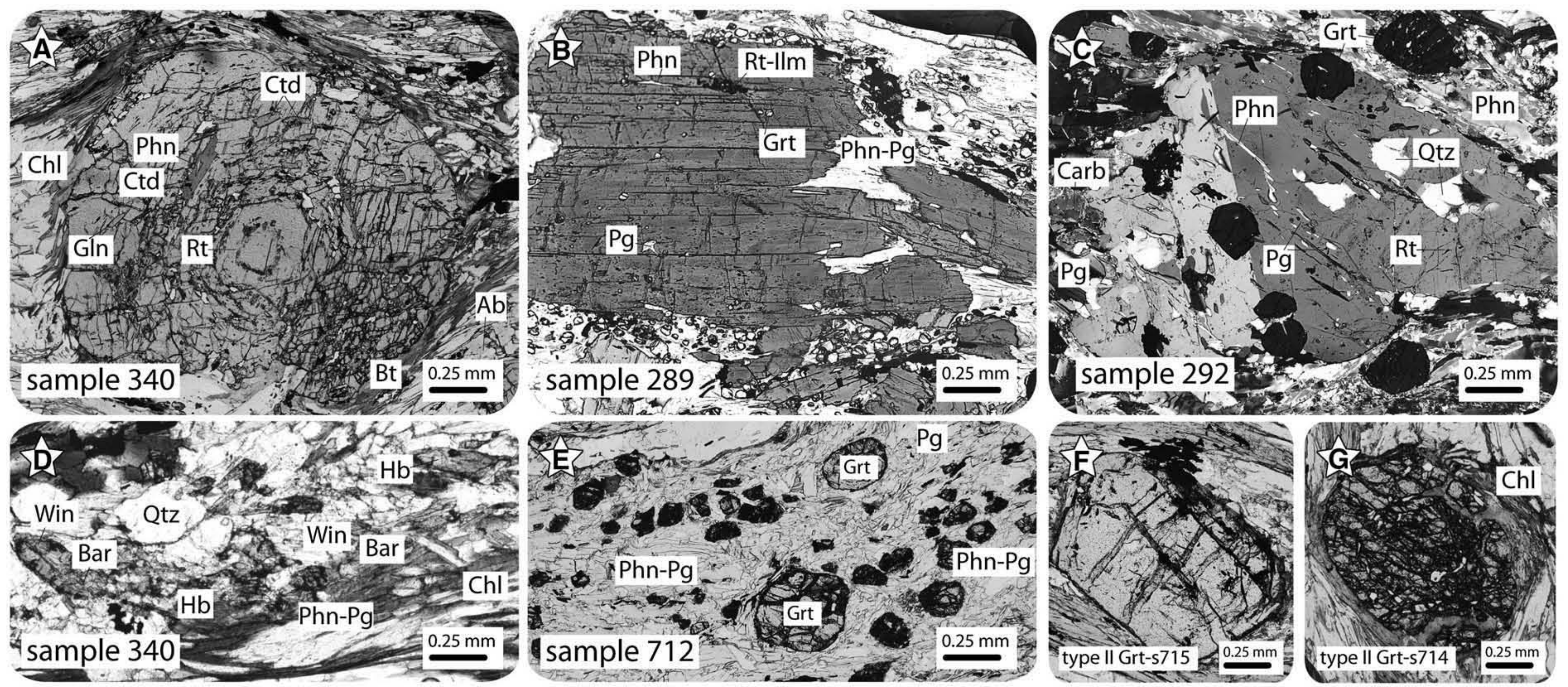

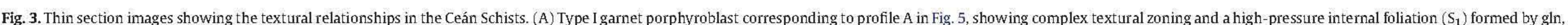

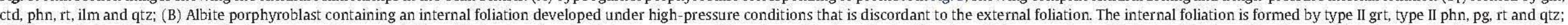

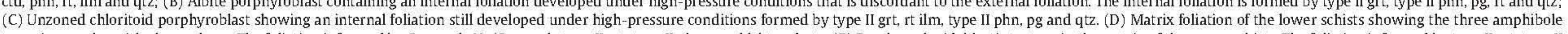

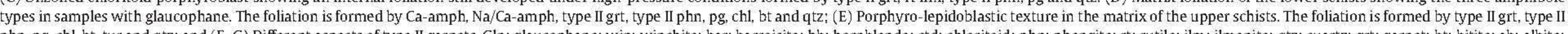

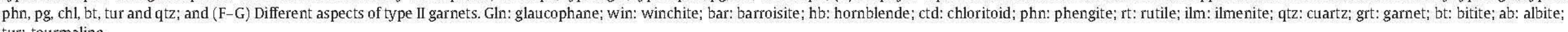
tur: tourmaline. 


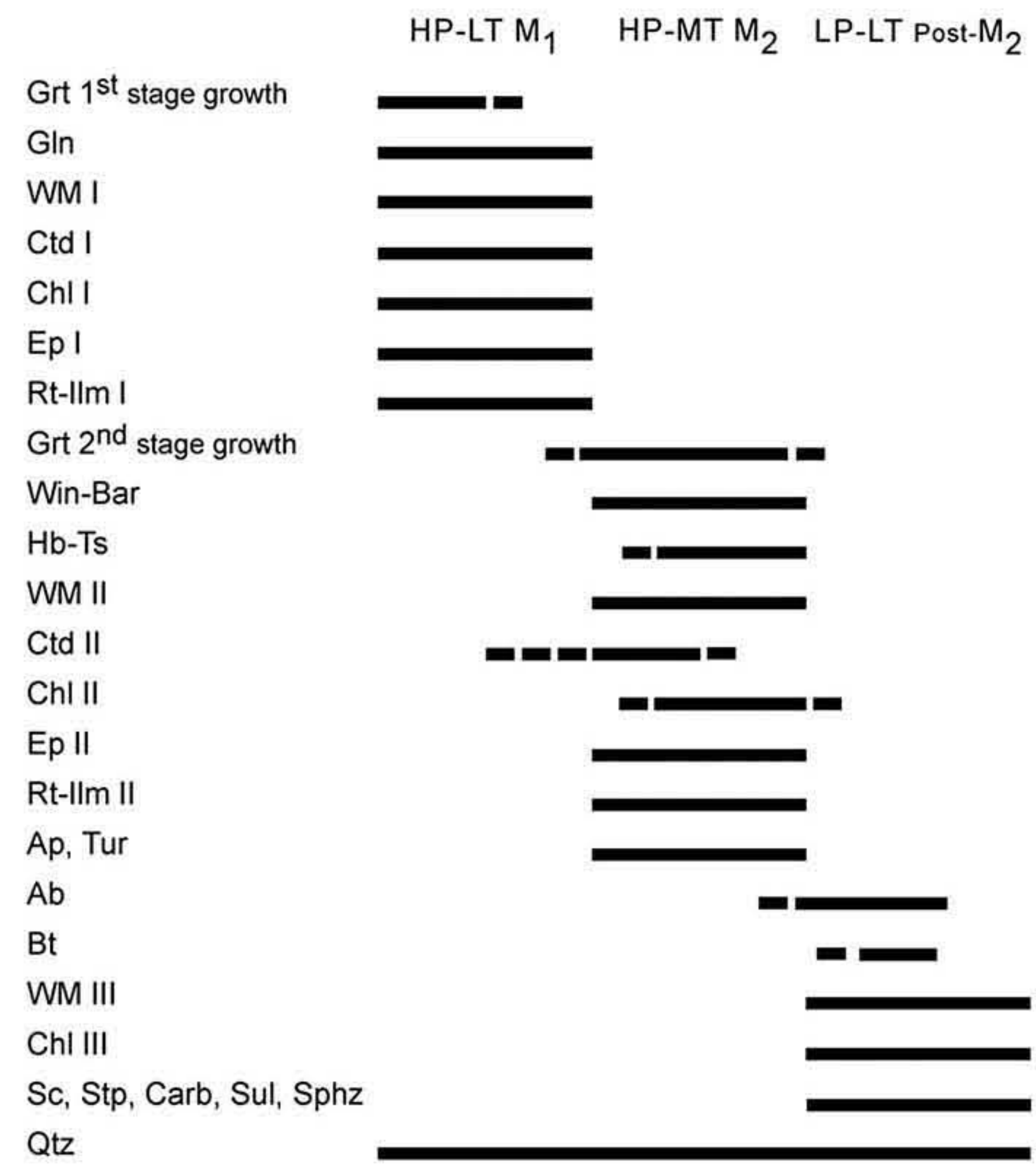

Fig. 4. Mineral crystallization diagram for the Ceán Schists.

content in the type I phengites of the Cean Schists is not found in the Santiago Schists, suggesting that the pressure peak was higher in the Ceán Schists.

Table 1

Representative microprobe analysis of coexisting $\mathrm{M}_{1}$ minerals.

\begin{tabular}{|c|c|c|c|c|c|c|c|}
\hline Sample & 340 & 340 & 339 & 340 & 340 & 340 & 340 \\
\hline Mineral & Grt Core & Phn & $\mathrm{Pg}$ & Gln & Ctd & Chl & Ep \\
\hline Analysis & 146 & 4 & 3 & 2 & 3 & 43 & 9 \\
\hline $\mathrm{SiO}_{2}$ & 37.96 & 50.92 & 45.75 & 56.79 & 23.81 & 25.93 & 38.13 \\
\hline $\mathrm{TiO}_{2}$ & 0.25 & 0.19 & 0.05 & 0.03 & 0.02 & 0.07 & 0.04 \\
\hline $\mathrm{Al}_{2} \mathrm{O}_{3}$ & 22.77 & 27.44 & 38.97 & 11.78 & 39.06 & 21.23 & 26.26 \\
\hline $\mathrm{Cr}_{2} \mathrm{O}_{3}$ & 0.07 & 0.05 & 0.06 & 0.01 & 0.05 & 0.04 & 0.11 \\
\hline $\mathrm{Fe}_{2} \mathrm{O}_{3}$ & 0.00 & 0.00 & 0.00 & 0.98 & 1.97 & 0.00 & 11.07 \\
\hline $\mathrm{FeO}$ & 24.22 & 3.51 & 1.07 & 11.86 & 22.27 & 21.82 & 0.10 \\
\hline MnO & 3.87 & 0.03 & 0.00 & 0.04 & 0.36 & 0.15 & 0.19 \\
\hline $\mathrm{MgO}$ & 0.60 & 2.35 & 0.22 & 10.04 & 3.20 & 16.44 & 0.00 \\
\hline $\mathrm{CaO}$ & 9.95 & 0.00 & 0.05 & 0.41 & 0.01 & 0.04 & 22.21 \\
\hline $\mathrm{Na}_{2} \mathrm{O}$ & 0.05 & 0.28 & 7.61 & 6.43 & 0.03 & 0.03 & 0.00 \\
\hline $\mathrm{K}_{2} \mathrm{O}$ & 0.02 & 10.20 & 0.41 & 0.02 & 0.00 & 0.02 & 0.00 \\
\hline Total & 99.76 & 94.97 & 94.19 & 98.39 & 90.78 & 85.77 & 98.11 \\
\hline \multicolumn{8}{|c|}{ Data calculated with AX software (Holland and Powell, 1998) } \\
\hline $\mathrm{Si}$ & 3.00 & 3.42 & 2.97 & 7.81 & 1.00 & 2.74 & 2.99 \\
\hline $\mathrm{Ti}$ & 0.01 & 0.01 & 0.00 & 0.00 & 0.00 & 0.01 & 0.00 \\
\hline Al & 2.12 & 2.17 & 2.98 & 1.91 & 1.94 & 2.64 & 2.43 \\
\hline $\mathrm{Cr}$ & 0.00 & 0.00 & 0.00 & 0.00 & 0.00 & 0.00 & 0.01 \\
\hline $\mathrm{Fe}^{3+}$ & 0.00 & 0.00 & 0.00 & 0.10 & 0.06 & 0.00 & 0.65 \\
\hline $\mathrm{Fe}^{2+}$ & 1.60 & 0.19 & 0.06 & 1.37 & 0.78 & 1.93 & 0.01 \\
\hline $\mathrm{Mn}$ & 0.26 & 0.00 & 0.00 & 0.01 & 0.01 & 0.01 & 0.01 \\
\hline $\mathrm{Mg}$ & 0.07 & 0.23 & 0.02 & 2.06 & 0.20 & 2.59 & 0.00 \\
\hline $\mathrm{Ca}$ & 0.84 & 0.00 & 0.00 & 0.06 & 0.00 & 0.01 & 1.87 \\
\hline $\mathrm{Na}$ & 0.01 & 0.04 & 0.96 & 1.72 & 0.00 & 0.01 & 0.00 \\
\hline K & 0.00 & 0.87 & 0.03 & 0.00 & 0.00 & 0.00 & 0.00 \\
\hline $\mathrm{X}_{\mathrm{Mg}}$ & 0.02 & 0.54 & 0.26 & 0.60 & 0.20 & 0.57 & \\
\hline$X_{\mathrm{Na}}$ & & 0.04 & 0.97 & 0.97 & & & \\
\hline$X_{\mathrm{Fe}}$ & & 0.46 & 0.73 & 0.05 & 0.79 & 0.43 & 0.21 \\
\hline
\end{tabular}

$\mathrm{X}_{\mathrm{Mg}}=\mathrm{Mg} /(\mathrm{Mg}+\mathrm{Fe})(\mathrm{Phn}, \mathrm{Pg}, \mathrm{Gln}, \mathrm{Ctd}, \mathrm{Chl}) ; \mathrm{X}_{\mathrm{Mg}}=\mathrm{Mg} /(\mathrm{Fe}+\mathrm{Mn}+\mathrm{Mg}+\mathrm{Ca})(\mathrm{Grt}) ;$ $\mathrm{X}_{\mathrm{Fe}}=\mathrm{Fe}^{3+} /\left(\mathrm{Fe}^{3+}+\mathrm{Al}\right)(\mathrm{Gln}, \mathrm{Ep}) ; \mathrm{X}_{\mathrm{Na}}=\mathrm{Na} /(\mathrm{Na}+\mathrm{K})(\mathrm{Phn}, \mathrm{Pg}) ; \mathrm{X}_{\mathrm{Na}}=\mathrm{Na} /(\mathrm{Na}+\mathrm{Ca})$ (Gln).

\subsection{Biotite}

Biotites appear as small bundles, 3-4 mm in length, with compositions intermediate between annite and phlogopite (calculated using the method of Holdaway et al., 1988) and low $\mathrm{TiO}_{2}$ contents $(<2 \mathrm{w} \%)$. The wide range in $\mathrm{X}_{\mathrm{Fe}}$ and $\mathrm{TiO}_{2}$ values suggests a relatively wide margin for their crystallization.

\subsection{Chlorite}

Type I chlorites are notably more magnesian $\left(\mathrm{X}_{\mathrm{Mg}} \approx 0.57\right)$ than type II chlorites $\left(\mathrm{X}_{\mathrm{Mg}} \approx 0.40\right)$.

\subsection{Chloritoid}

Both chloritoid types are moderately rich in $\mathrm{FeO}$, with $\mathrm{X}_{\mathrm{Fe}}$ ranging from 0.80 to 0.84 in type I and type II respectively, and no core-rim zonation. Their compositions are characteristic of medium pressure chloritoids in paragenesis with garnet, staurolite and/or kyanite (Deer et al., 1992). The observed decrease in $\mathrm{X}_{\mathrm{Mg}}$ between type I chloritoid inclusions $\left(\mathrm{X}_{\mathrm{Mg}} \approx 0.20\right)$ and type II chloritoid porphyroblasts $\left(X_{M g} \approx 0.16\right)$ suggest a slight increase in temperature from $M_{1}$ to $M_{2}$.

\subsection{Epidote}

Epidote shows a restricted range of composition and no core-rim zonation with $\mathrm{X}_{\mathrm{Fe}} \approx 0.20$ for both type I and type II.

\subsection{Plagioclase}

Plagioclase is nearly pure albite with maximum anorthite and orthose contents of 0.28 and $0.16 w$ t.\%, respectively, in samples without glaucophane, and 3.84 and $0.42 \mathrm{wt} \%$ in samples with glaucophane.

\subsection{Sphene and Fe-Ti oxides}

Sphene is not chemically zoned and shows low $\mathrm{Al}_{2} \mathrm{O}_{3}$ contents that reach a maximum (2.04 wt.\%) in the samples without glaucophane. Rutile is nearly pure and ilmenite shows a wide range of chemical variation.

\section{Phase equilibria and $P-T$ evolution}

Three metamorphic episodes corresponding to the paragenetic events $M_{1}, M_{2}$ and post- $M_{2}$ have been established from the petrography of the Cean Schists. Only the first two can be quantified provided since the mineralogy corresponding to the third episode is insufficient for evaluating the $P-T$ conditions.

$\mathrm{M}_{1}$ is recorded in the oldest paragenesis observed in the schists, represented by a relict schistosity preserved as micro-inclusions in garnet, albite and chloritoid porphyroblasts, and defined by a mineral assemblage $\mathrm{Grt}+\mathrm{Phn}+\mathrm{Pg}+\mathrm{Gln}+\mathrm{Ctd}+\mathrm{Chl}+\mathrm{Ep}+\mathrm{Rt}-$ $\mathrm{Ilm}+$ Qtz. This assemblage defines a fine-grained foliation $\left(S_{1}\right)$ developed under high- $P$ and low-T conditions. $\mathrm{M}_{2}$ correspond to the main foliation $\left(S_{2}\right)$ and represents an evolution of $S_{1}$ to slightly higher temperatures and lower pressures, as indicated by the mineral paragenesis $\mathrm{Grt}+\mathrm{Phn}+\mathrm{Pg}+\mathrm{Win}+\mathrm{Bar}+\mathrm{Hb}-\mathrm{Ts}+\mathrm{Ctd}+\mathrm{Chl}+$ $\mathrm{Ep} / \mathrm{Czo}+\mathrm{Rt}-\mathrm{Ilm}+\mathrm{Ap}+\mathrm{Tur}+\mathrm{Qtz} \pm \mathrm{Ab}$.

Different methods were applied to the quantification of the $M_{1}$ and $\mathrm{M}_{2}$ metamorphic events in the chloritoid-glaucophane Ceán pelitic schists, including conventional thermobarometric techniques, average $P-T$ multiequilibrium thermobarometry, and thermodynamic modelling in appropriate chemical systems. A data summary showing the techniques applied and the results obtained is listed in Table 4. 
Table 2

Representative microprobe analysis of coexisting $\mathrm{M}_{2}$ minerals.

\begin{tabular}{|c|c|c|c|c|c|c|c|c|c|c|c|c|c|}
\hline Samples & 340 & 336 & 336 & 340 & 340 & 340 & 340 & 340 & 289 & 340 & 340 & 340 & 340 \\
\hline Mineral & Grt Rim & Phn & $\mathrm{Pg}$ & $\mathrm{Fe}-\mathrm{Hb}$ & $\mathrm{Mg}-\mathrm{Hb}$ & Ts & Win & Bar & Ctd & Chl & Bt & Ep & $\mathrm{Ab}$ \\
\hline Analysis & 207 & 215 & 59 & 16 & 17 & 24 & 11 & 26 & 134 & 67 & 13 & 18 & 85 \\
\hline $\mathrm{SiO}_{2}$ & 37.95 & 49.04 & 46.7 & 44.54 & 44.94 & 47.23 & 53.96 & 46.75 & 24.28 & 24.61 & 36.54 & 38.04 & 67.25 \\
\hline $\mathrm{TiO}_{2}$ & 0.06 & 0.28 & 0.07 & 0.27 & 0.26 & 0.23 & 0.14 & 0.10 & 0.06 & 0.06 & 1.55 & 0.15 & 0.00 \\
\hline $\mathrm{Al}_{2} \mathrm{O}_{3}$ & 21.78 & 28.25 & 39.38 & 12.48 & 12.74 & 10.40 & 13.28 & 9.43 & 41.69 & 23.15 & 16.71 & 26.68 & 19.87 \\
\hline $\mathrm{Cr}_{2} \mathrm{O}_{3}$ & 0.00 & 0.00 & 0.00 & 0.08 & 0.04 & 0.12 & 0.04 & 0.00 & 0.05 & 0.00 & 0.10 & 0.09 & 0.00 \\
\hline $\mathrm{Fe}_{2} \mathrm{O}_{3}$ & 0.00 & 0.00 & 0.08 & 1.56 & 5.61 & 4.51 & 0.00 & 6.05 & 0.00 & 0.00 & 0.00 & 9.75 & 0.03 \\
\hline $\mathrm{FeO}$ & 32.71 & 3.68 & 1.09 & 15.13 & 11.63 & 11.93 & 14.01 & 11.99 & 22.18 & 29.14 & 18.36 & 0.09 & 0.00 \\
\hline $\mathrm{MnO}$ & 0.46 & 0.00 & 0.01 & 0.44 & 0.45 & 0.51 & 0.47 & 0.42 & 0.15 & 0.41 & 0.18 & 0.08 & 0.03 \\
\hline MgO & 1.55 & 2.26 & 0.25 & 8.28 & 10.74 & 11.20 & 7.32 & 11.29 & 2.30 & 10.84 & 11.57 & 0.04 & 0.00 \\
\hline $\mathrm{CaO}$ & 6.58 & 0.02 & 0.08 & 9.68 & 10.19 & 9.80 & 6.14 & 8.88 & 0.00 & 0.00 & 0.00 & 23.20 & 0.06 \\
\hline $\mathrm{Na}_{2} \mathrm{O}$ & 0.01 & 0.36 & 6.02 & 1.06 & 1.59 & 1.77 & 1.63 & 2.40 & 0.01 & 0.01 & 0.02 & 0.02 & 10.92 \\
\hline $\mathrm{K}_{2} \mathrm{O}$ & 0.00 & 10.29 & 2.23 & 0.39 & 0.37 & 0.30 & 0.62 & 0.25 & 0.03 & 0.01 & 9.79 & 0.02 & 0.03 \\
\hline Total & 101.1 & 94.18 & 95.91 & 93.92 & 98.55 & 98.01 & 97.61 & 97.57 & 90.75 & 88.23 & 94.82 & 98.16 & 98.19 \\
\hline \multicolumn{14}{|c|}{ Data calculated with AX software (Holland and Powell, 1998) } \\
\hline $\mathrm{Si}$ & 3.00 & 3.33 & 2.99 & 6.81 & 6.54 & 6.88 & 7.60 & 6.88 & 1.01 & 2.63 & 2.79 & 2.98 & 2.98 \\
\hline $\mathrm{Ti}$ & 0.00 & 0.01 & 0.00 & 0.03 & 0.03 & 0.03 & 0.01 & 0.01 & 0.00 & 0.00 & 0.09 & 0.01 & 0.00 \\
\hline Al & 2.03 & 2.26 & 2.97 & 2.25 & 2.19 & 1.79 & 2.21 & 1.64 & 2.04 & 2.91 & 1.50 & 2.46 & 1.04 \\
\hline $\mathrm{Cr}$ & 0.00 & 0.00 & 0.00 & 0.01 & 0.00 & 0.01 & 0.01 & 0.00 & 0.00 & 0.00 & 0.00 & 0.00 & 0.00 \\
\hline $\mathrm{Fe}^{3+}$ & 0.00 & 0.00 & 0.00 & 0.18 & 0.61 & 0.49 & 0.00 & 0.67 & 0.00 & 0.00 & 0.00 & 0.57 & 0.00 \\
\hline $\mathrm{Fe}^{2+}$ & 2.16 & 0.21 & 0.06 & 1.94 & 1.42 & 1.45 & 1.65 & 1.48 & 0.77 & 2.60 & 1.17 & 0.01 & 0.00 \\
\hline $\mathrm{Mn}$ & 0.03 & 0.00 & 0.00 & 0.06 & 0.06 & 0.06 & 0.06 & 0.05 & 0.00 & 0.04 & 0.01 & 0.01 & 0.00 \\
\hline $\mathrm{Mg}$ & 0.18 & 0.23 & 0.02 & 1.89 & 2.33 & 2.43 & 1.54 & 2.48 & 0.14 & 1.72 & 1.32 & 0.00 & 0.00 \\
\hline $\mathrm{Ca}$ & 0.56 & 0.00 & 0.00 & 1.56 & 1.59 & 1.52 & 0.93 & 1.40 & 0.00 & 0.00 & 0.00 & 1.95 & 0.00 \\
\hline $\mathrm{Na}$ & 0.00 & 0.05 & 0.75 & 0.32 & 0.45 & 0.50 & 0.45 & 0.69 & 0.00 & 0.00 & 0.00 & 0.00 & 0.94 \\
\hline K & 0.00 & 0.89 & 0.18 & 0.08 & 0.07 & 0.06 & 0.11 & 0.05 & 0.00 & 0.00 & 0.95 & 0.00 & 0.00 \\
\hline $\mathrm{X}_{\mathrm{Mg}}$ & 0.06 & 0.52 & 0.29 & 0.49 & 0.62 & 0.63 & 0.48 & 0.63 & 0.16 & 0.39 & 0.53 & & \\
\hline $\mathrm{X}_{\mathrm{Na}}$ & & 0.05 & 0.80 & 0.17 & 0.22 & 0.25 & 0.33 & 0.33 & & & & & \\
\hline $\mathrm{X}_{\mathrm{Fe}}$ & & 0.48 & 0.71 & 0.07 & 0.22 & 0.21 & 0.00 & 0.29 & 0.84 & 0.60 & 0.47 & 0.19 & \\
\hline An & & & & & & & & & & & & & 0.28 \\
\hline $\mathrm{Ab}$ & & & & & & & & & & & & & 99.57 \\
\hline Or & & & & & & & & & & & & & 0.16 \\
\hline
\end{tabular}

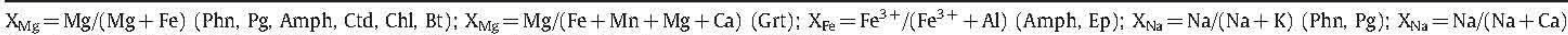
$($ Amph $) ; \mathrm{An}=[\mathrm{Ca} /(\mathrm{Ca}+\mathrm{Na}+\mathrm{K})] 100, \mathrm{Ab}=[\mathrm{Na} /(\mathrm{Ca}+\mathrm{Na}+\mathrm{K})] 100, \mathrm{Or}=[\mathrm{K} /(\mathrm{Ca}+\mathrm{Na}+\mathrm{K})] 100$.

Garnet-Phengite thermometry (Hynes and Forest, 1988), and GRIPS (Bohlen and Liotta, 1986) and GASP (Koziol, 1989; Holdaway, 2001) barometry calculations using micro-inclusion compositions, indicate peak conditions around $P=19-22 \mathrm{kbar}$ and $T=420-500{ }^{\circ} \mathrm{C}$. The same calculations using the $\mathrm{S}_{2}$ fabric minerals yield approximate values of $P=16-20 \mathrm{kbar}$ and $\mathrm{T}=440-515{ }^{\circ} \mathrm{C}$ (Fig. 7).

The average $P-T$ multiequilibrium thermobarometry using THERMOCALC 3.26 (Powell and Holland, 1988) with the internally consistent thermodynamic dataset of Holland and Powell (1998; updated 22 Nov. 2003), provides more consistent $P-T$ values. These are essentially in agreement with the conventional thermobarometry results, but show significantly lower pressures for the $M_{2}$ stage. Average $P-T$ calculations using micro-inclusion compositions indicate peak conditions between $P=19-20 \mathrm{kbar}$ and $\mathrm{T}=425-430^{\circ} \mathrm{C}$. The values obtained using the matrix mineral compositions are $P=13-$
$14 \mathrm{kbar}$ and $\mathrm{T}=495-500^{\circ} \mathrm{C}$ (Fig. 7.). In general, we consider the estimates obtained using the average $P-T$ calculations to be more reliable because the same thermodynamic data and activity-composition models are used for all the calculations (Powell and Holland, 2008). However, the results of conventional thermobarometry show a similar range of $P-T$ values, suggesting that this technique is not without merit.

Thermodynamic modeling of rocks or compositional volumes in rocks (effective bulk composition or equilibration volume) has been shown to be one of the most powerful methods for obtaining information about the metamorphic evolution of terranes. P-T pseudosections, in particular, allow a system to be modeled for the composition of interest and the parageneses observed in the rock to be compared with the ones predicted by the phase diagram. Pseudosections also let the observed parageneses in a particular

Table 3

Stages of garnet growth according to the structural position of the samples in which they occur.

\begin{tabular}{|c|c|c|c|c|}
\hline \multirow{2}{*}{$\begin{array}{l}\text { Samples } \\
\text { Lower structural levels }\end{array}$} & \multicolumn{2}{|c|}{ 1st stage } & \multicolumn{2}{|c|}{ 2nd stage } \\
\hline & Grt IC & & $\begin{array}{l}\text { Grt IR } \\
\text { Grt IIC }\end{array}$ & $\begin{array}{l}\text { Grt IIR } \\
\text { Grt IIAb }\end{array}$ \\
\hline $\begin{array}{l}\text { Higher structural levels } \\
\text { End-member components }\end{array}$ & & $\begin{array}{l}\text { Grt ICtd } \\
\text { Grt IC }\end{array}$ & & Grt IR \\
\hline & $\operatorname{Alm}_{[0.58]} P y_{[0.03]} \operatorname{GrS}_{(0.38)} S_{p s}(0.09)$ & $\begin{array}{l}\operatorname{Alm}_{(0.61)} P_{(0.05)} \operatorname{Grs}_{(0.18)} S^{S p s}(0.16) \\
A_{(0.57)} P_{(0.04)} \operatorname{Grs}_{(0.15)} S_{(0.23)}\end{array}$ & $\begin{array}{l}\operatorname{Alm}_{(0.68)} \mathrm{Py}_{(0.04)} \mathrm{Grs}_{(0.25)} \mathrm{Sps}_{(0.03)} \\
\mathrm{Alm}_{(0.67)} \mathrm{Py}_{(0.04)} \mathrm{Grs}_{(0.24)} \mathrm{Sps}_{(0.05)}\end{array}$ & $\begin{array}{l}\operatorname{Alm}_{(0.73)} \mathrm{Py}_{(0.06)} \mathrm{Grs}_{(0.15)} \mathrm{Sps}_{(0.06)} \\
\operatorname{Alm}_{(0.73)} \mathrm{Py}(0.07) \mathrm{Grs}_{(0.14)} \mathrm{Sps}_{(0.07)} \\
\operatorname{Alm}_{(0.70)} \mathrm{Py}(0.07) \mathrm{Grs}_{(0.15)} \mathrm{Sps}_{(0.08)}\end{array}$ \\
\hline
\end{tabular}

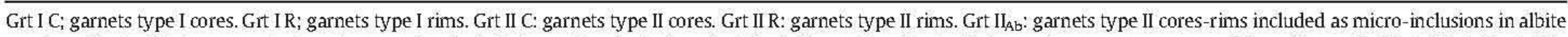

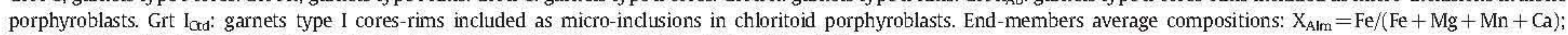
$\mathrm{X}_{\mathrm{Py}}=\mathrm{Mg} /(\mathrm{Fe}+\mathrm{Mg}+\mathrm{Mn}+\mathrm{Ca}) ; \mathrm{XGrs}=\mathrm{Ca} /(\mathrm{Fe}+\mathrm{Mg}+\mathrm{Mn}+\mathrm{Ca}) ; \mathrm{XSps}=\mathrm{Mn} /(\mathrm{Fe}+\mathrm{Mg}+\mathrm{Mn}+\mathrm{Ca})$. 

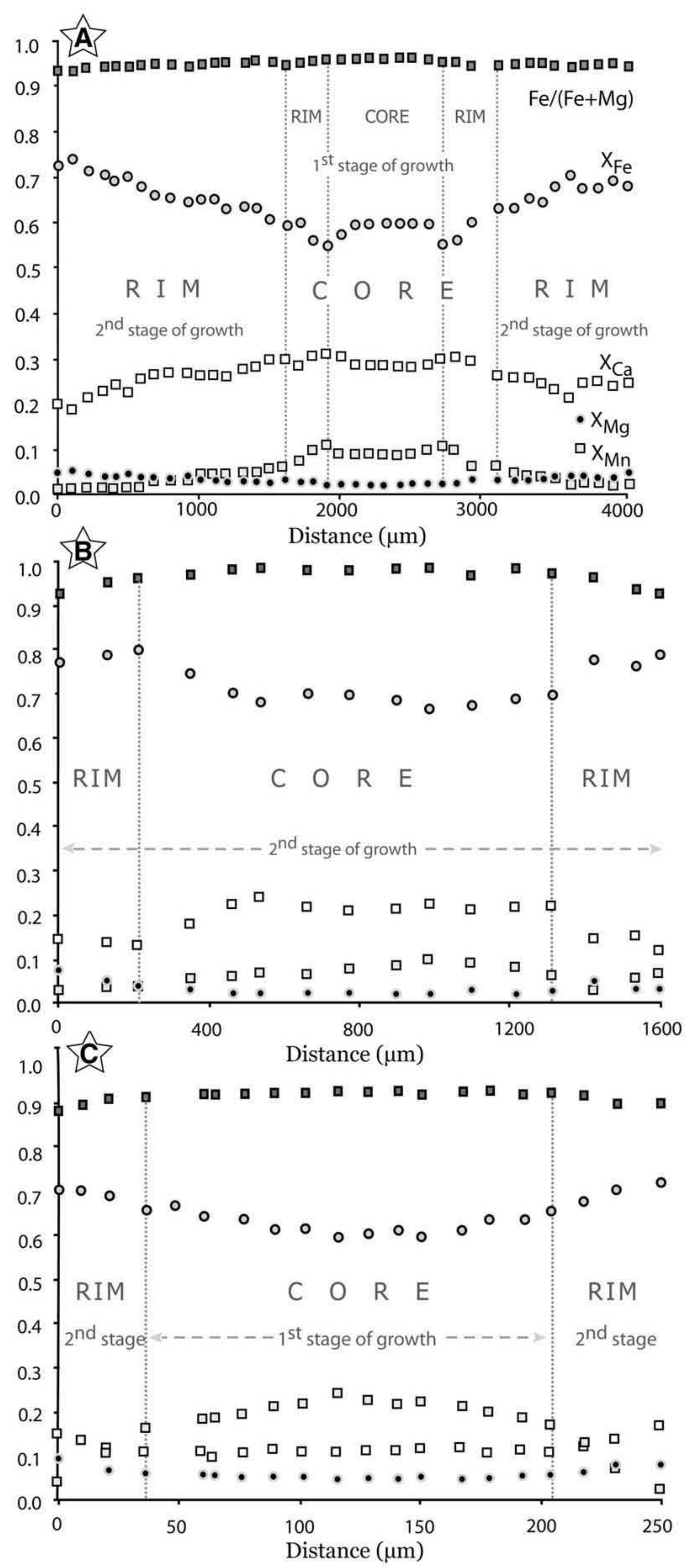

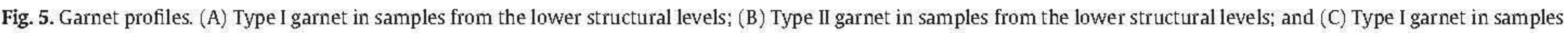
from the upper structural levels. 


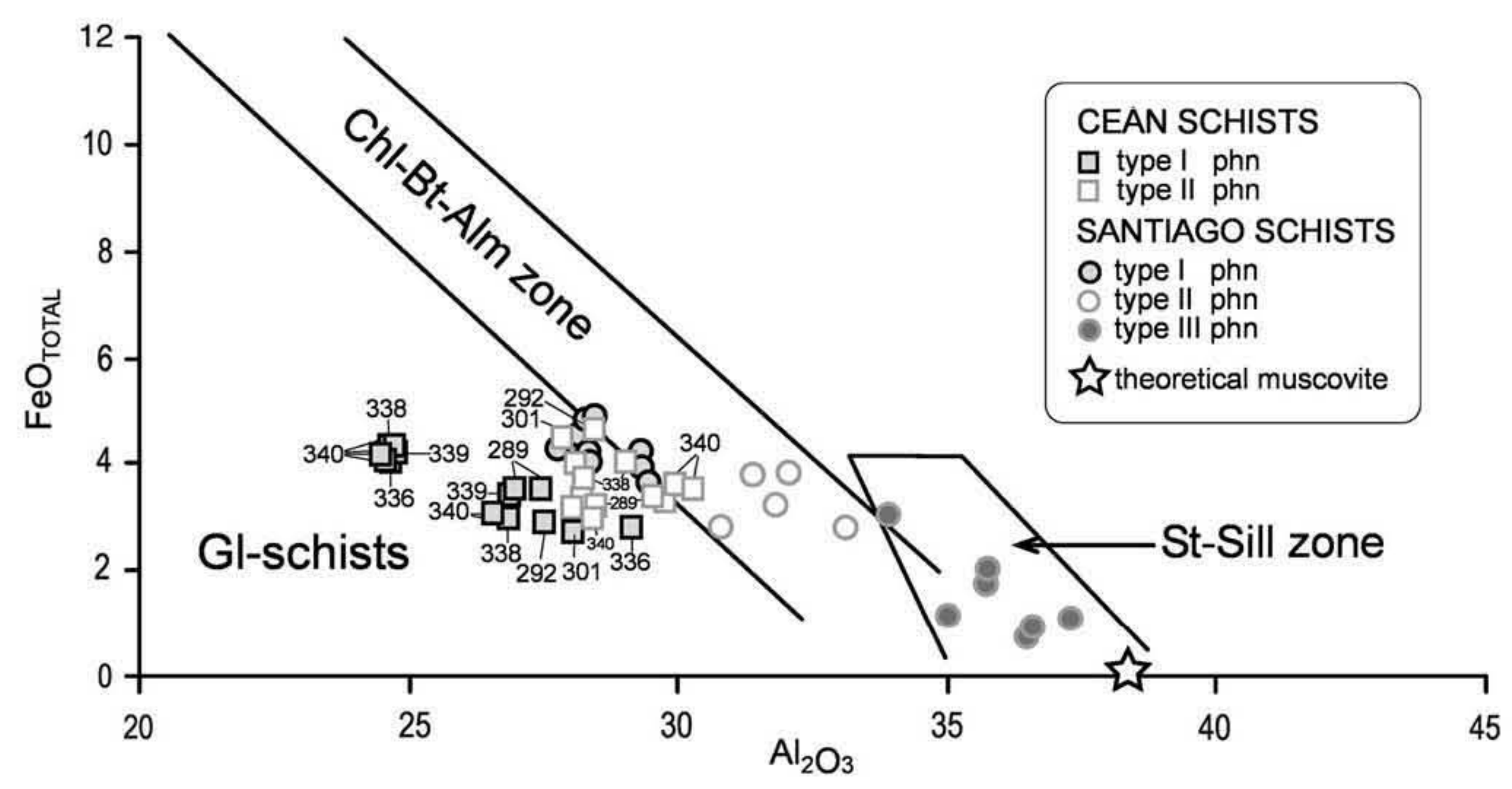

Fig. 6. White mica classification diagram based on metamorphic origin (Miyashiro, 1973).

Table 4

Summary of the thermobarometric techniques.

\begin{tabular}{|c|c|c|c|c|c|c|}
\hline & $\mathrm{M}_{1}$ & $\mathrm{P}_{1}($ kbar $) ; \mathrm{T}_{1}\left({ }^{\circ} \mathrm{C}\right)$ & $\mathrm{M}_{2}$ & $\mathrm{P}_{2}($ kbar $) ; \mathrm{T}_{2}\left({ }^{\circ} \mathrm{C}\right)$ & \multicolumn{2}{|c|}{ Chemical composition } \\
\hline Conventional thermobarometry & $\begin{array}{l}\text { Peak } \\
\text { paragenesis } \\
\left(\mathrm{S}_{1}\right)\end{array}$ & $19-22 ; 420-500$ & $\begin{array}{l}\text { Matrix } \\
\text { paragenesis } \\
\left(\mathrm{S}_{2}\right)\end{array}$ & $16-20 ; 440-515$ & $\begin{array}{l}\mathrm{M}_{1} \\
\mathrm{~S}_{1} \text { minerals } \\
\text { Table } 1\end{array}$ & $\begin{array}{l}\mathrm{M}_{2} \\
\mathrm{~S}_{2} \text { minerals } \\
\text { Table } 2\end{array}$ \\
\hline Average $P-T$ calculations & $\begin{array}{l}\text { Peak } \\
\text { paragenesis } \\
\left(\mathrm{S}_{1}\right)\end{array}$ & $19.3 ; 454(\sigma=1.5)$ & $\begin{array}{l}\text { Matrix } \\
\text { paragenesis } \\
\left(S_{2}\right)\end{array}$ & $13.7 ; 493(\sigma=1.5)$ & $\begin{array}{l}\mathrm{M}_{1} \\
\mathrm{~S}_{1} \text { minerals } \\
\text { Table } 1\end{array}$ & $\begin{array}{l}\mathrm{M}_{2} \\
\mathrm{~S}_{2} \text { minerals } \\
\text { Table } 2\end{array}$ \\
\hline \multicolumn{3}{|l|}{$n$-variant fields } & \multicolumn{4}{|l|}{ Bulk composition } \\
\hline \multicolumn{7}{|c|}{ Theoretic major elements pelites composition } \\
\hline $\begin{array}{l}\text { (Atherton and Brotherton, } 198 \\
\text { KFMASH pseudosection }\end{array}$ & $\mathrm{CrChlCtd}$ & $\begin{array}{l}\text { MnNCKFMASH } \\
\text { Chl Grt }\end{array}$ & \multicolumn{4}{|c|}{$\begin{array}{l}{\left[\mathrm{SiO}_{2}: 70.14 ; \mathrm{Al}_{2} \mathrm{O}_{3}: 13.22 ; \mathrm{CaO}: 1.29 ; \mathrm{MgO}: 4.08 ; \mathrm{FeO}: 6.14 ; \mathrm{K}_{2} \mathrm{O}: 2.62 ; \mathrm{Na}_{2} \mathrm{O}: 2.38 ; \mathrm{MnO}: 0.12\right]} \\
{\left[\mathrm{SiO}_{2}: 71.42 ; \mathrm{Al}_{2} \mathrm{O}_{3}: 13.42 ; \mathrm{MgO}: 4.78 ; \mathrm{FeO}: 7.04 ; \mathrm{K}_{2} \mathrm{O}: 3.34\right]}\end{array}$} \\
\hline MnNCKFMASH pseudosection & Gl Chl Ctd Grt Lw & Gl Chl Grt Pa & \multicolumn{4}{|c|}{$\left[\mathrm{SiO}_{2}: 68.73 ; \mathrm{Al}_{2} \mathrm{O} 3: 13.78 ; \mathrm{CaO}: 1.46 ; \mathrm{MgO}: 4.49 ; \mathrm{FeO}: 6.55 ; \mathrm{K}_{2} \mathrm{O}: 3.37 ; \mathrm{Na}_{2} \mathrm{O}: 1.39 ; \mathrm{MnO}: 0.23\right]$} \\
\hline
\end{tabular}

rock be placed in the context of alternative mineral assemblages, such as when phases are no longer stable, or when additional minerals join the parageneses. In addition, pseudosections are not dependent on establishing original mineral compositions, which is an important advantage, especially in texturally complex rocks (Powell and Holland, 2008) like those considered here.

We computed two pseudosections using the average bulk rock composition of the Ceân Schists (samples EC-G3 and EC-G4) obtained by whole-rock analysis as the equilibration volume (Fig. 8; Table 4) since, in fluid-saturated rocks, this is generally a good approximation of the effective bulk composition (Tajčmanová et al., 2007). Fig. 8 is an ACF ternary diagram that shows the protolith composition. Samples EC-G3 and EC-G4 are classified as pelites (Turner, 1981; Vernon and Clarke, 2008). The first pseudosection was computed in the KFMASH system, widely used for pelitic rocks. However, while this proved useful as a first approximation, the importance of Na-bearing minerals in these rocks made it necessary the widening the system to one involving at least $\mathrm{Na}$. For this reason we computed a second pseudosection in the MnNCKFMASH system.

The KFMASH pseudosection was calculated using Thermocalc 3.26 (Powell and Holland, 1988) and the internally consistent thermodynamic dataset (Holland and Powell, 1998; updated Nov. 2003). It is based on the petrogenetic grid proposed by Wei and Powell (2003) for a synopsis of high-P metapelites with similar bulk rock compositions to those of the Ceán Schists. The most obvious limitations of the pseudosection obtained, which are primarily due to the absence of $\mathrm{Mn}, \mathrm{Na}$ and $\mathrm{Ca}$ components, and: (1) the limited mineral associations that can be computed, and (2) the unrealistic stability field predicted for garnet, which appears only above $550^{\circ} \mathrm{C}$. This makes the comparison of the mineral assemblages present in the schists with the predicted associations in the $P-T$ diagram almost useless, as some of the key minerals relevant to these rocks, such as amphiboles, paragonite and albite, are not represented (Fig. 9).

However, the comparison between both phase diagrams is useful for visualizing the influence of $\mathrm{Ca}$ and $\mathrm{Mn}$, small amounts of which can strongly influence garnet stability (Spear and Cheney, 1989; Symmes and Ferry, 1992; Mahar et al., 1997). The effect of adding these components generally results in a dramatic widening of the garnet stability field (see e.g. Tinkham et al., 2003; Proyer, 2003; Boger and Hansen, 2004; Zuluaga et al., 2005). The most useful aspect of this pseudosection is in the ability to plot isopleths for silica content in phengite in the different stability fields (dashed lines in Fig. 9), which provides an accurate barometer (e.g. Massone and Schreyer, 1987) that is essentially in agreement with the pressure values obtained from average $P-T$ calculations at the same temperatures.

The $P-T$ pseudosection in the model MnNCKFMASH system has been calculated with Perplex vs. 07 (Connolly, 2005; http:/ www. perplex.ethz.ch/) using the internally consistent thermodynamic dataset (Holland and Powell. 1998; updated Nov. 2003) for the same bulk rock composition (Table 4). The solution models used (see details and references in the file solut08.dat; PERPLEX 07; database hp02ver.dat) are Gt(HP), $\mathrm{Mica}(\mathrm{CH} 2), \mathrm{Bio}(\mathrm{HP}), \mathrm{Chl}(\mathrm{HP}), \mathrm{Ctd}(\mathrm{HP}), \mathrm{Pl}$ (h), Gl, and Carp. The P-T pseudosection obtained shows several lowsloped limits between key mineral associations, which can be used as sensitive pressure indicators. The low-P limit of the paragenesis 


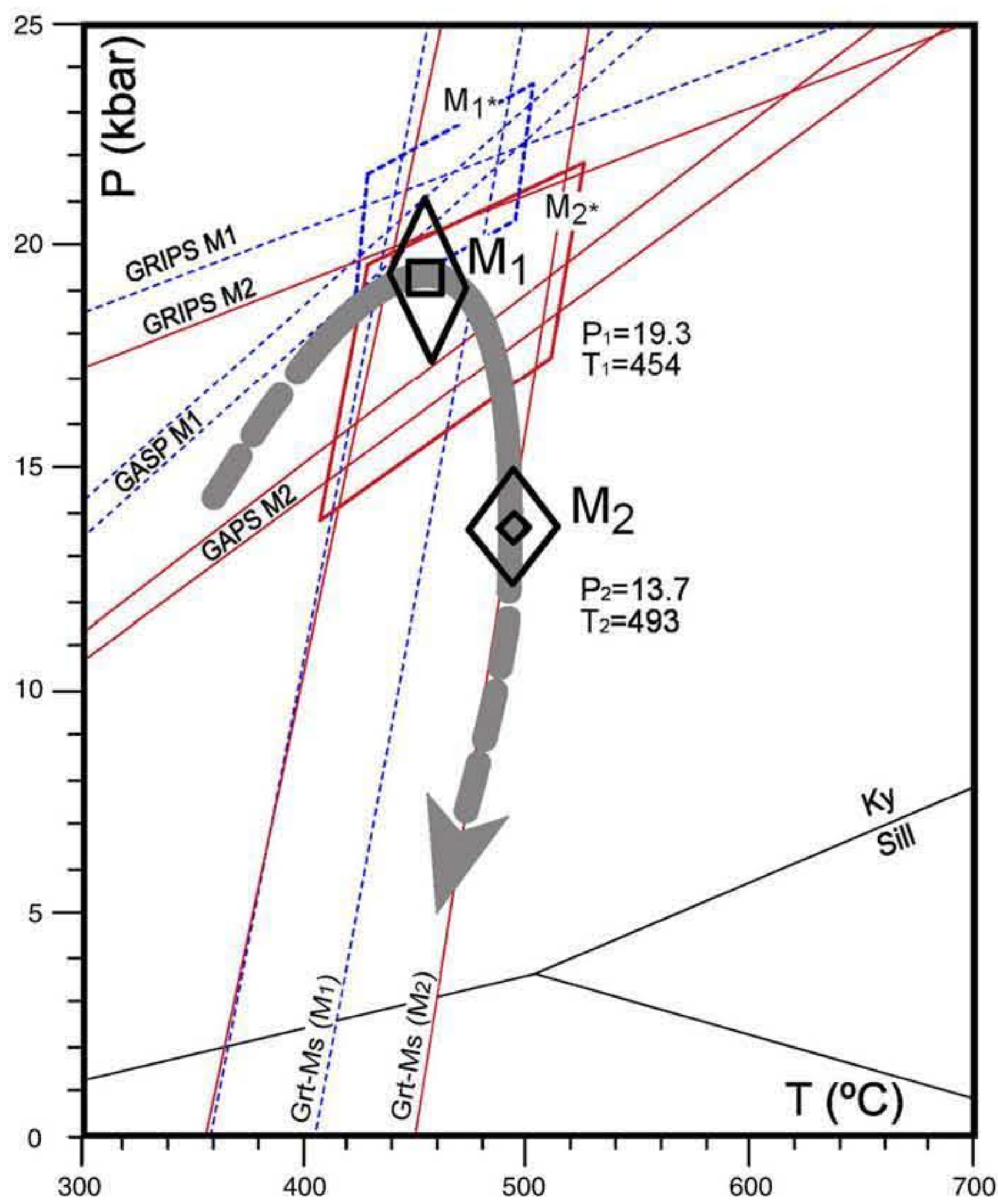

Fig. 7. Conventional thermobarometry results and Average $P-T$ calculation. For Themocalc, the $1.5 \sigma$ errors are automatically calculated. For the conventional thermobarometers, errors were estimated on the basis of their upper and lower limits based on compositional variations. chloritoid + glaucophane at $\approx 17$ kbar (Fig. 10) constrains the conditions for the $\mathrm{M}_{1}$ event and confirms the high- $P$ character of this association. The stable phases accompanying chloritoid and glaucophane are garnet, lawsonite and chlorite, whereas paragonite appears at these pressures only above $500{ }^{\circ} \mathrm{C}$. Lawsonite is the only high- $P$ phase predicted that has not been observed either as inclusions in garnet or in the matrix. However, pseudomorphs of this mineral are not uncommon in the interbedded mafic rocks, and some of the abundant crystals of zoisite/clinozoisite found in the matrix of the schists are likely to have formed at the expense of lawsonite. The limit of the stability field of plagioclase is another useful indicator. The growth of late albite porphyroblasts in some levels indicates a dramatic decompression from the fields with chloritoid + glaucophane to the fields with stable albite. We can place further constrains from the fact that part of the samples contain biotite in $S_{2}$, indicating that the $P-T$ path should first go through fields with biotite and then through those with albite. The path that best fits the petrographic data starts in the field Chl, Ctd, Gl, Law (Fig. 10) and evolves through Chl, Ctd, Gl, Gt, Law, Pa and Chl, Gl, Gt, Pa (with the formation of new paragonite and the disappearance of lawsonite), to enters the field $\mathrm{Bt}, \mathrm{Chl}, \mathrm{Gt}, \mathrm{Zo}$, $\mathrm{Pa}$ to form biotite (Fig. 10) and, finally, to Chl, Gt, Zo, Pa, $\mathrm{Ab}$ (pervasive albite porphyroblast growth). This $P-T$ path suggests strong decompression, from more than 17 to $7 \mathrm{kbar}$, with moderate heating to a peak around $500-525{ }^{\circ} \mathrm{C}$. The isopleths of silica content in phengite are also valuable pressure indicators (Fig. 10-B). The mean content in the $S_{1}$ phengites is close to 3.4 cations p.f.u., whereas it is slightly lower (3.3 cationsp.f.u.) in the $S_{2}$ phengites. This indicates pressures above 17-18 kbar for $\mathrm{M}_{1}$ and around 12-13 kbar for $\mathrm{M}_{2}$, assuming the temperature ranges indicated by the stability field of the parageneses and the average $P-T$ Thermocalc multiequilibrium thermobarometry.

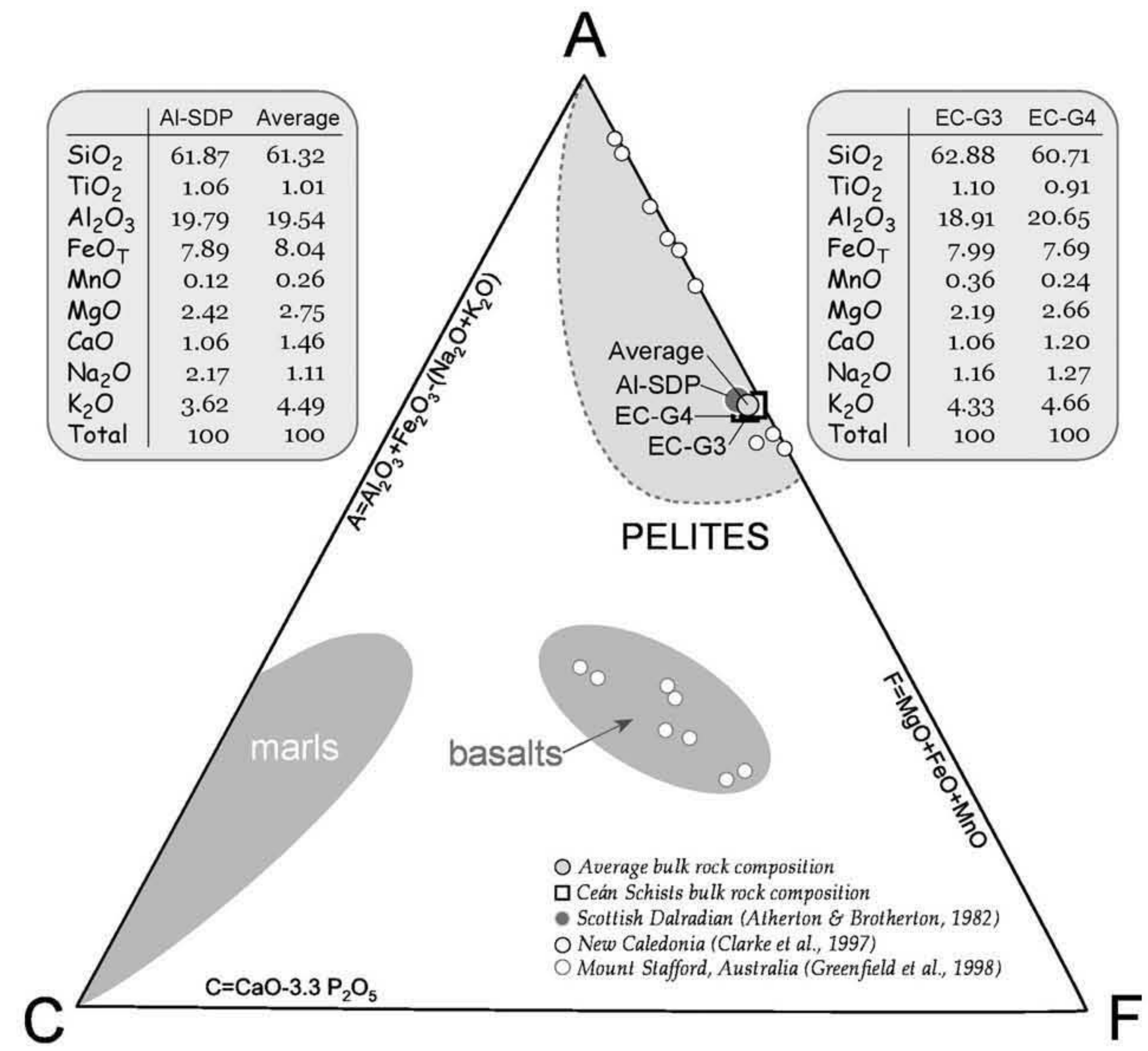

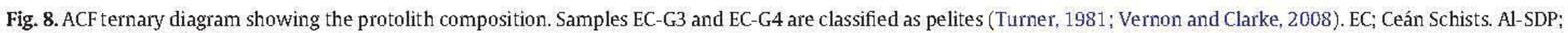
aluminous Scottish Dalradian Pelite. 


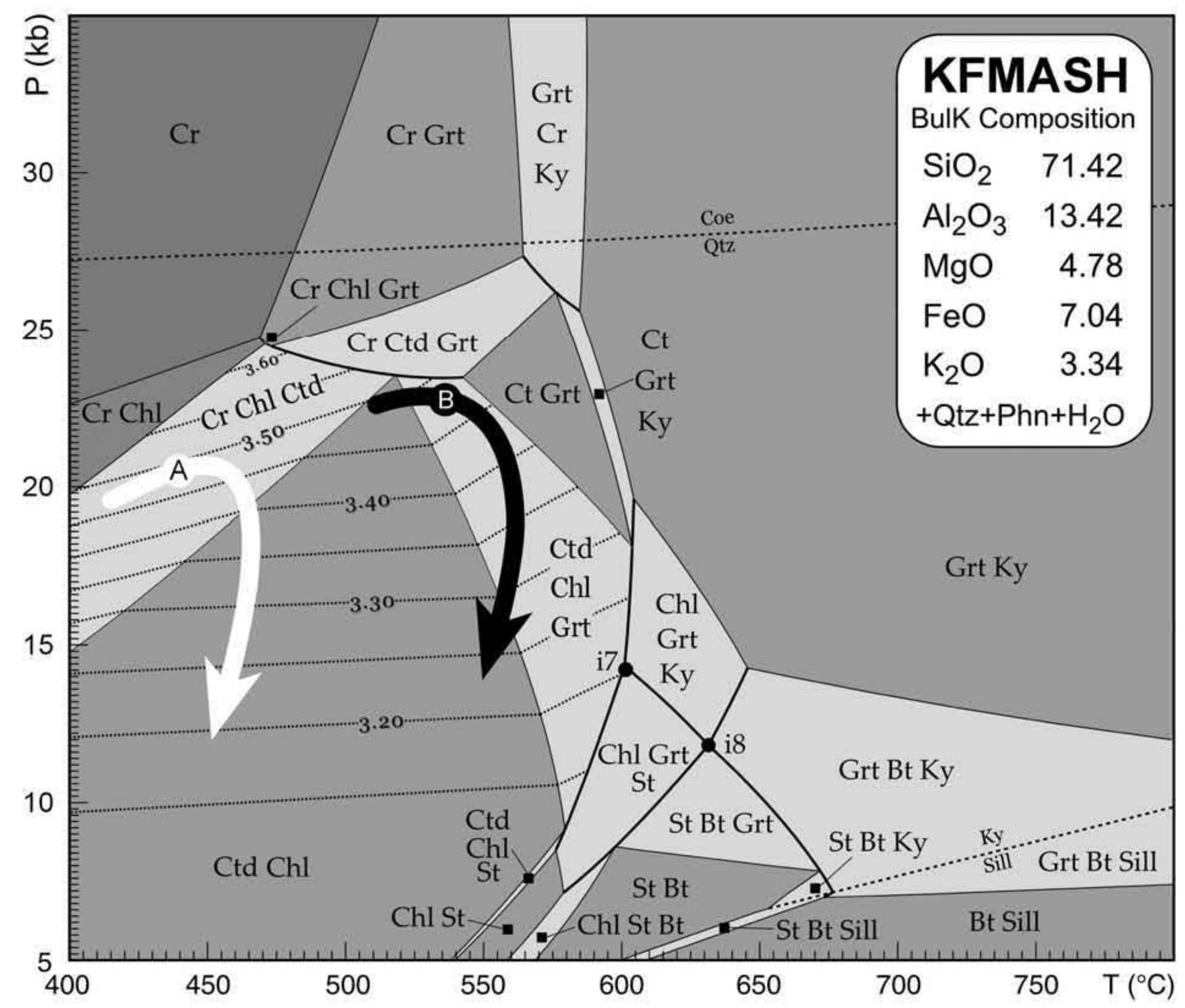

Fig. 9. KFMASH pseudosection calculated with Thermocalc program v.3.26. The dashed lines show the silica content in phengite (c.p.f.u).

\section{Conclusions}

The main conclusions of this study are:

1. The stability field of the $M_{1}$ paragenesis containing glaucophane + chloritoid is located, for the composition of the pelitic Ceán Schists, above $17-18 \mathrm{kbar}$. Hence, the $P-T$ path deduced from all the data obtained in this study indicates an initial stage of subduction burial to a depth of $65-70 \mathrm{~km}$. Maximum burial was followed by dramatic exhumation with slight heating, reaching a metamorphic peak at $\sim 500^{\circ} \mathrm{C}$. This slight increase in temperature during decompression is supported by the presence of late biotite in chemical imbalance with the rest of the $\mathrm{M}_{2}$ minerals, suggesting an origin related to a localized heating that could have taken place during the exhumation of the unit.

2. The secondary growth of $\mathrm{Na}-\mathrm{Ca}$ amphiboles, most likely after glaucophane, indicate that, although it has not been identified in the matrix of the schists, it was a stable phase during the second high-pressure event. The sodic-calcic amphiboles and coexisting hornblende occur as intergrowths and occur only in the matrix of samples containing glaucophane as garnet inclusions. This intergrowth texture can be interpreted in two ways: as an amphibole miscibility gap and as a disequilibrium growth texture. Reynard and Ballevre (1988) demostrated the existence of a miscibility gap between sodic and calcic amphiboles at $T=500-550^{\circ} \mathrm{C}$, which suggests that glaucophane and hornblende could have coexisted during $\mathrm{M}_{2}$. However, textural observations in the $\mathrm{Na}-\mathrm{Ca}$ amphiboles of the Ceán Schist show chemical zonation indicating disequilibrium growth. Therefore, these amphiboles cannot be considered as an intermediate stage between the two endmembers (Reynard and Ballèvre, 1988). They are compatible with amphibole formation during retrograde fluid infiltration under high-P conditions, as described, for example, by Menold et al. (2001) and Shi et al. (2003).

3. A preliminary pseudosection in the basic pelitic KFMASH shows the significant influence of $\mathrm{Mn}$ and $\mathrm{Ca}$ components on the stability of garnet, leading to an overestimation of the temperature. However, the pressure calculated with silica isopleths in the same diagram corresponds well with the other barometric calculations.

4. The MnNCKFMASH system pseudosection fully describes the succession of mineral assemblages in the schists, and produces results that are consistent with the petrographic observations.

5. There are several studies focused on the metamorphic evolution of different parts of the Basal Units, a compilation of which is given in Martínez Catalán et al. (1996). These authors see the Basal Units as a coherent terrane and propose that the differences in the P-T conditions and geometry of the $P-T$ paths observed in the diverse sub-units are essentially related to their position in the subduction complex. The consistent increase in the pressure peak registered from east to west (present coordinates) in the Basal Units was used to deduce a westward polarity for the subduction that is consistent with the east-vergence of the nappes and folds in the internal zones of the orogen in the NW Iberian Massif. In this context, the P-T path obtained for the Ceán Schists is consistent with their location in the western part of the basal sheet, registering the highest pressures obtained in the entire Basal Units. Their low-T evolution in the blueschist facies contrasts with the rest of the Malpica-Tui unit, where the metamorphic peak is developed in the medium-T eclogite facies. However, their evolution is quite similar to the nearby Santiago Schists in the Ordenes Complex (Arenas et al., 1995). The peak pressure of the Ceán Schists is $20 \mathrm{kbar}$, whereas in the Santiago Schists, located to the east of Malpica, it is $16 \mathrm{kbar}$. Thus, it is possible to separate the Basal Units in two different types according to their metamorphic evolution and position: an upper blueschist type and a lower eclogite facies type. 

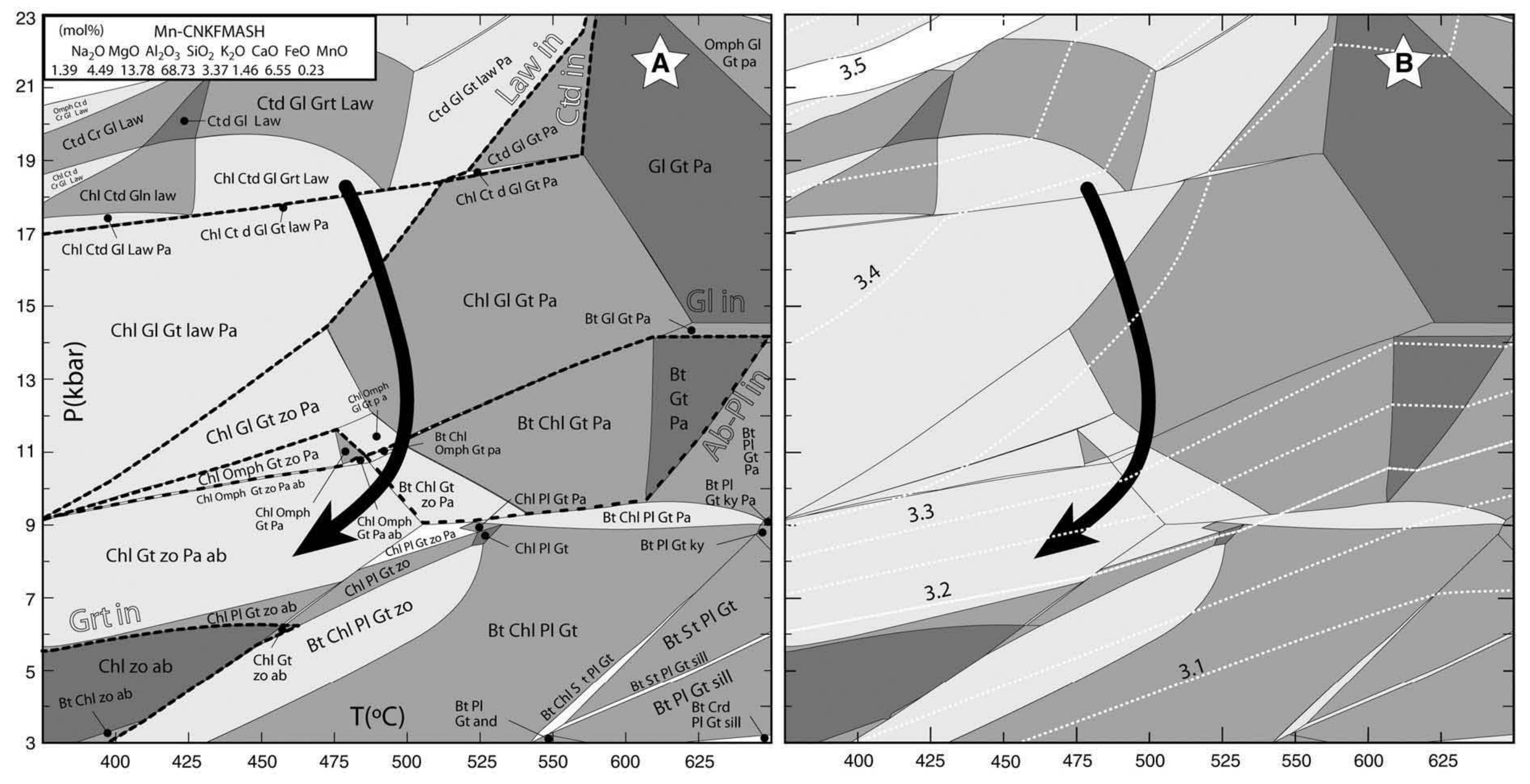

Fig. 10. (A) MnNCKFMASH pseudosection calculated with Perplex 07 software, and (B) Isopleths for Si-content in phengite (c.p.f.u). 


\section{Acknowledgements}

This work was financially supported by the CGL2007-65338-C02-01 project. We thank Dr. Pavel Pitra and Dr. Michel Ballèvre for broadening our perspectives. We also thank the Guest Editor Dr. Damian Nance, Dr. Ricardo Arenas and two anonymous reviewers for their constructive comments and suggestions that significantly improved the final manuscript. We also wish to thank A. Larios and J. Tánago, from the Luis Bru Electronic Microscopy Centre, for their technical support.

\section{References}

Abati, L.L., Gerdes, A., Fernández Suárez, J., Arenas, R, Whitehouse, M.J., Díez Fernández, R., 2009. Magmatism and early-Variscan continental subduction in the northern Gondwana margin recorded in zircons from the basal units of Galicia, NW Spain. Geological Society of America Bulletin 122 (1-2), 219-235.

Alonso, L.L, González, J.C., 1982. Mapa Geológico Nacional Sisargas-Carballo. Instituto Geológico y Minero de España, Hoja 44, scale 1:50.000.

Arenas, R., Rubio Pascual, F., Díaz-García, F., Martínez Catalán, J.R., 1995. High-pressure micro-inclusions and development o fan inverted metamorphic gradient in the Santiago Schists (Órdenes Complex, NW Iberian Massif, Spain): evidence of subduction and syncollisional decompression. Joumal of Metamorphic Geology 13, 141-164.

Arenas, R., Abati, J., Martínez Catalan, J.R., Díaz Garcia, F., Rubio Pascual, F.J., 1997. P-T evolution of eclogites from the Agualada Unit (Ordenes Complex, northwest Iberian Massif, Spain): Implications for crustal subduction. Lithos 40, 221-242.

Arps, C.E.S., 1981. Amphibolites and other mafic rocks of the Blastomylonitic Graben in Western Galicia, NW Spain: Field relations and petrography. Leidse Geologische Mededelingen 52, 57-71.

Atherton, M.P., 1968. The variation in garnet, biotite and chlorite composition in medium grade pelitic rocks from the Dalradian, Scotland, with particular reference to the zonation in garnet. Contributions to Mineralogy and Petrology 18, 347-371.

Atherton, M.P., Brotherton, M.S., 1982. Major element composition of the pelites of the Scottish Dalradian. Geological Journal 17, 185-221.

Babist, J., Handy, M.R., Konrad-Schmolke, M., Hammerschmidt, K., 2006. Precollisional, multistage exhumation of subducted continental crust: the Sesia Zone, western Alps. Tectonics 25, TC6008. doi:10.1029/2005TC001927.

Ballevre, M., Pitra, P., Bohn, M., 2003. Lawsonite growth in the epidote blueschists from the Ile de Groix (Armorican Massif, France): a potential geobarometer. Journal of Metamorphic Geology 21, 723-735.

Ballèvre, M., Bosse, V., Ducassou, C., Pitra, P., 2009. Palaeozoic history of the Armorican Massif: models for the tectonic evolution of the suture zones. Comptes Rendus Geosciences 34, 174-201.

Behr, H.J., Engel, W., Franke, W., Giese, P., Weber, K., 1984. The Variscan Belt in Central Europe: main structures, geodynamic implications, open questions. Tectonophysics 109, 15-40.

Boger, S.D., Hansen, D., 2004. Metamorphic evolution of the Georgetown Inlier, northeast Queensland, Australia; evidence for an accreted Palaeoproterozoic terrane? Journal of Metamorphic Geology 22, 511-527.

Bohlen, S.R., Liotta, J.J., 1986. A barometer for garnet amphibolites and garnet granulites. Jounal of Petrology 27, 1025-1034.

Bosse, V., Feraud, G., Ballevre, M., Peucat, J.-J., Corsini, M., 2005. Rb-Sr and ${ }^{40} \mathrm{Ar} /{ }^{39} \mathrm{Ar}$ ages in blueschists from the Ile de Groix (Armorican Massif, France): implications for closure mechanisms in isotopic systems. Chemical Geology 220, 21-45.

Chakraborty, S., Ganguly, J., 1991. Compositional zoning and cation diffusion in aluminosilicate garnets. In: Ganguly, J. (Ed.), Diffusion atomic ordering and mass transport: selected problems in geochemistry. Springer-Verlag, New York, pp. 120-170.

Chopin, C., 1981. Talc-phengite: a widespread assemblage in high-grade pelitic blueschists of the Western Alps. Journal of Petrology 22, 628-650.

Coke, C., Ribeiro, A., 2000. Malpica-Lamego shear zone: a major crustal discontinuity in the Iberian Variscan fold belt. In: Arenas, et al. (Ed.), Excursion guidebook, Program and Abstracts. Galicia 2000: 15th International Conference on Basement Tectonics: Variscan-Appalachian dynamics: The building of the Upper Paleozoic Basement. A Coruña, Spain, pp. 208-210.

Connolly, J.A.D., 2005. Computation of phase equilibria by linear programming: a tool for geodymamic modeling and its application to subduction zone decarbonation. Earth and Planetary Science Letters 236, 524-541.

Cymerman, Z., Piasecki, M.A.J., Seston, R., 1997. Terranes and terrane boundaries in the Sudetes, Northeast Bohemian Massif. Geological Magazine 134, 717-725.

Deer, W.A., Howie, R.A., Zussman, J., 1992. An introduction to the rock-forming minerals. Prentice Hall, London.

El-Shazly, A.K., Liou, J.G., 1991. Glaucophane-chloriotid-bearing assemblages from NE Oman: petrologic significance and petrogenetic grid for HP metapelites. Contributions to Mineralogy and Petrology 107, 180-201.

Emst, W.G., 1973. Blueschists metamorphism and $P-T$ regimes in active subduction zones. Tectonophysics $17,255-272$.

Ernst, W.G., 2001. Subduction, ultrahigh-pressure metamorphism, and regurgitation of buoyant crustal slices-implications for arcs and continental growth. Physics of the Earth and Planetary Interiors 127, 253-275.

Fernández-Suárez, J., Arenas, R., Abati, J., Martínez Catalán, J.R., Whitehouse, M.J.. Jeffries, T. 2007. U-Pb Chronometry of polimetamorphic high-pressure granulites: an example from the allochthonous terranes of the NW Iberian Variscan belt. In: HatcherJr. Jr., R.D., Carlson, M.P., McBride, J.H., Martínez Catalán, J.R. (Eds.), 4-D framework of continental crust: Geological Society of America Memoir, vol. 200, pp. 469-488.
Gil Ibarguchi, J.I., Ortega Gironés, E., 1985. Petrology, structure and geotectonic implications of glaucophane-bearing eclogites and related rocks from the Malpica-Tuy unit, Galicia, northwest Spain. Chemical Geology 50, 145-162.

Hirajima, T., Compagnoni, R., 1993. Petrology of a jadeite-quartz/coesite almandinephengite fels with retrograde ferro-nyböite from the Dora-Maira Massif, Western Alps. European Journal of Mineralogy 5, 943-955.

Holdaway, M.J., 2001. Recalibration of the GASP geobarometer in light of recent garnet and plagioclase activity models and versions of the garnet-biotite geothermometer American Mineralogist 86, 1117-1129.

Holdaway, M.J., Dutrow, B.L., Hinton, RW., 1988. Devonian and carboniferous metamorphism in west-central Maine; the muscovite-almandine geobarometer and the staurolite problem revisited. American Mineralogist 73, 20-47.

Holland, T.J.B., Powell, R., 1998. An internally consistent thermodynamic data set for phases of petrological interest. Journal of Metamorphic Geology 16, 309-343.

Hollister, LS., 1966. Garnet zoning: an interpretation based on the Rayleigh fractionation model. Science 154, 1647-1651.

Hynes, A., Forest, R.C., 1988. Empirical garnet-muscovite geothermometry in low-grade metapelites, Selwyn Range (Canadian Rockies). Journal of Metamorphic Geology 6, 297-309.

Katagas, C, 1980. Ferroglaucophane and chloritoid-bearing metapelites from the phyllite series, southern Peloponnes, Greece. Mineralogical Magazine 43, 975-978.

Kiénast, J.R., Triboulet, C, 1972. Le chloritoïde dans les paragenèses à glaucophane, albite ou paragonite. Bulletin de la Societe Francaise Minéralogie et de Cristallographie 95, $565-573$.

Koziol, A.M., 1989. Recalibration of the garnet-plagioclase- $\mathrm{Al}_{2} \mathrm{SiO}_{5}$-quartz (GASP) geobarometer and application to natural parageneses. American Geophysical Union Spring Meeting, vol. 70. EOS, Baltimore, Maryland, p. 493.

Kretz, R., 1983. Symbols for rock-forming minerals. American Mineralogist 68, $277-279$.

Kryza, R., Muszynski, A., Vielzeuf, D., 1990. Glaucophane-bearing assemblage overprinted by greenschist-facies metamorphism in the Variscan Kaczawa complex. Sudetes, Poland. Journal of Metamorphic Geology 8, 345-355.

Kurata, H., Banno, S., 1974. Low-grade progressive metamorphism of Pelitic Schists of the Sazare area, Sanbagawa Metamorphic Terrain in central Sikoku, Japan. Journal of Petrology 15, 361-382.

Llana-Fúnez, S., 2001. La estructura de la unidad de Malpica-Tui (Cordillera varisca en Iberia). Ph.D. thesis, Instituto Geológico y Minero de España, Madrid.

Llana-Fúnez, S., Marcos, A., 2002. Structural record during exhumation and emplacement of high-pressure-low-to intermediate-temperature rocks in the Malpica-Tui unit (Variscan Belt of Iberia). In: Martínez Catalán, J.R., HatcherJr Jr, R.D., Arenas, R., Díaz Garcia, F. (Eds.), Variscan-Appalachian dymamics: The building of the late Paleozoic bassamen: Geological Society of America-Special Paper, vol. 364, pp. 125-142.

López-Carmona, A., Abati, J., Reche, J., 2008. Evolución Metamórfica de los Esquistos de AP/BT de Ceán (Unidad de Malpica-Tui, NW del Macizo Ibérico). Geogaceta $43,3-6$.

Mahar, E.M., Baker, J.M., Powell, R., Holland, T.J.B., Howell, N., 1997. The effect of Mn on mineral stability in metapelites. Journal of Metamorphic Geology 15, 223-238.

Martínez Catalán, J.R., Arenas, R., Díaz García, F., Rubio Pascual, F.J., Abati, J., Marquínez, J., 1996. Variscan exhumation of a subducted Paleozoic continenta margin: the basal units of the Ordenes Complex, Galicia, NW Spain. Tectonics 15, 106-121.

Martínez Catalán, J.R., Arenas, R., Díaz García, F., Gómez Barreiro, J., González Cuadra, P. Abati, J., Castiñeiras, P., Fernández Suárez, J., Sánchez Martínez, S., Andonaegui, P., González Clavijo, E., Díez Montes, A., Rubio Pascual, F.J., Valle Agudo, B., 2007. Space and time in the tectonic evolution of the northwestern Iberian Massif. Implications for the comprehension of the Variscan belt. In: Hatcher, R.D.J., Carlson, M.P., McBride, J.H., Martínez Catalán, J.R. (Eds.), 4-D framework of continental crust: The Geological Society of America Memoir, vol. 200, pp. 403-423.

Martínez Catalán, J.R., Arenas, R., Abati, J., Sánchez Martínez, S., Díaz García, F., Fernández Suárez, J., González Cuadra, P., Castiñeiras, P., Gómez Barreiro, J., Díez Montes, A. González Clavijo, E., Rubio Pascual, F.J., Andonaegui, P., Jeffries, T.E., Alcock, J.E., Díez Fernández, R., López-Carmona, A., 2009. A rootless suture and the loss of the roots of a mountain chain: the Variscan belt of NW Iberia. Comptes Rendus Geosciences 341 , 114-126.

Maruyama, S., Liou, G., Terabayashi, M., 1996. Blueschists and eclogites of the world International Geology Review 38, 485-594.

Masago, H., Omori, S., Maruyama, S., 2009. Counter-clockwise prograde $P-T$ path in collisional orogeny and water subduction at the Precambrian-Cambrian boundary: the ultrahigh-pressure pelitic schist in the Kokchetav massif, northern Kazakhstan. Gondwana Research 15, 137-150.

Massone, H.J., Schreyer, W., 1987. Phengite geobarometry based on the limiting assemblage with K-feldspar, phlogopite and quartz. Contributions to Mineralogy and Petrology 96, 212-214.

Matte, P.H., 1986. Tectonics and plate tectonics model for the Variscan belt of Europe Tectonophysics $126,329-374$.

Menold, C.A., Manning, C.E., Yin, A, Chen, X., 2001. Metamorphism and Exhumation of Very High-Pressure Eclogites, North Qaidam, China. 2001 AGU Fall Meeting, San Francisco: American Geophysical Union.

Miyashiro, A, 1973. Metamorphism and metamorphic belts. G. Allen and Unwin Publications, London.

Omori, S., Kita, S., Maruyama, S., Santosh, M., 2009. Pressure-temperature conditions of ongoing regional metamorphism beneath the Japanese Islands. Gondwana Research $16,458-469$.

Ortega, E., 1980. Aportaciones a la estructura geológica de los alrededores de Malpica, extremo septentrional de la Fosa Blastomilonítica, La Coruña. Cuadernos del Laboratorio Xeológico de Laxe 1, 177-186. 
Pin, C., Vielzeulf, D., 1988. Les granulites de hatte pression d'Europe moyenne témoins d'une subuctionéo-hercynienne. Implications surl'orgine des groupes leptyno- amphiboliques. Bulletin de la Societé Géologique de France 1, 13-20.

Platt, J.P., 1993. Exhumation of high-pressure rocks: a review of concepts and processes Terra Nova $5,119-133$

Powell, R., Holland, T.J.B., 1988. An internally consistent dataset with uncertainties and correlations: 3 . Applications to geobarometry, worked examples and a computer program. Journal of Metamorphic Geology 6, 173-204.

Powell, R., Holland, T.J.B., 2008. On thermobarometry. Journal of Metamorphic Geology $26,155-179$

Proyer, A, 2003. Metamorphism of pelites in NKFMASH-a new petrogenetic grid with implications for the preservation of high-pressure mineral assemblages during exhumation. Journal of Metamorphic Geology 21, 493-509.

Rảheim, A., 1977. Petrology of the Strathgordon area, western Tasmania: $\mathrm{Si}^{4+}$-content of phengite mica as a monitor of metamorphic grade. Journal of the Geological Society of Australia 24, 329-338.

Reynard, B., Ballèvre, M., 1988. Coexisting amphiboles in an eclogite from the Western Alps: new constraints on the miscibility gap between sodic and calcic amphiboles. Journal of Metamorphic Geology 6, 333-350.

Rodríguez Aller, J., 2005. Recristalización y deformación de litologías supracorticales sometidas a metamorfismo de alta presión (Complejo de Malpica-Tui, NO de Macizo Ibérico). Nova Terra, vol. 29. A Cortuña.

Rodríguez, J., Cosca, M.A., Gil Ibarguchi, J.I., Dallmeyer, R.D., 2003. Strain partitioning and preservation of ${ }^{40} \mathrm{Ar} /{ }^{39} \mathrm{Ar}$ ages during Variscan exhumation of a subducted crust (Malpica-Tui complex, NW Spain). Lithos 70, 111-139.

Santosh, M., Maruyama, S., Sato, K., 2009. Anatomy of a Cambrian suture in Gondwana: Pacific-type orogeny in southern India? Gondwana Research 16, 321-341.

Shelley, D., Bossière, G., 1999. Ile de Groix: retrogression and structural developments in an extensional régime. Journal of Structural Geology 21, 1441-1455.

Shi, G.-H., Cui, W.-Y., Tropper, P., Wang, C-Q., Shu, G.-M., Yu, H., 2003. The petrology of a complex sodic and sodic-calcic amphibole association and its implications for the metasomatic processes in the jadeitite area in northwestern Myanmar, formerly Burma. Contributions to Mineralogy and Petrology 145, 355-376.

Smelik, E.A., Veblen, D.R., 1992. Exsolution of Ca-amphibole from glaucophane and the miscibility gap between sodic and calcic amphiboles. Contributions to Mineralogy and Petrology 112, 178-195.

Song, S.-G., Zhang, L.-F., Niu, Y., Wei, C.-J., Liou, J-G., Shu, G.-M., 2007. Eclogite and carpholite-bearing metasedimentary rocks in the North Qilian suture zone, NW China: implications for Early Palaeozoic cold oceanic subduction and water transport into mantle. Joumal of Metamorphic Geology 25, 547-563.

Spear, F.S., 1995. Metamorphic phase equilibria and pressure-temperature-time paths. Mineralogical Society of America Monograph, Washington.
Spear, F., Cheney, J., 1989. A petrogenetic grid for pelitic schists in the System $\mathrm{SiO}_{2}-\mathrm{Al}_{2} \mathrm{O}_{3}-$ $\mathrm{FeO}-\mathrm{MgO}-\mathrm{K}_{2} \mathrm{O}-\mathrm{H}_{2} \mathrm{O}$. Contributions to Mineralogy and Petrology 101, 149-164.

Symmes, G.H., Ferry, J.M., 1992. The effect of whole-rock MnO content on the stability of garnet in pelitic schists during metamorphism. Journal of Metamorphic Geology 10, 221-237.

Tajčmanová, L., Konopásek, J., Connolly, J., 2007. Diffusion-controlled development of silica-undersaturated domains in felsic granulites of the Bohemian Massif (Variscan belt of Central Europe). Contributions to Mineralogy and Petrology 153, 237-250.

Theye, T., Seiidel, E., Vidal, O., 1992. Carpholite, sudoite and chloritoid in low-grade highpressure metapelites from Crete and the Peloponnese, Greece. European Journal of Mineralogy 4, 487-507.

Thompson, J.B.J., Laird, J., Thompson, A.B., 1982. Reactions in amphibolite, greenschist and blueschist. Joumal of Petrology 23, 1-27.

Tinkham, D.K., Zultuaga, C.A., Stowell, H.H., 2003. Metapelite phase equilibria modeling in MnNCKFMASH: The effect of variable $\mathrm{Al} 203$ and $\mathrm{MgO} /(\mathrm{MgO}+\mathrm{FeO})$ on mineral stability. American Mineralogist 88, 1174.

Turner, F.J., 1981. Metamorphic petrology, Mineralogical and Field Aspects, Second edition. McGraw-Hill, New York

Van Calsteren, P.W.C., Boelrijk, N.A.I.M., Hebeda, E.H., Priem, H.N.A., Tex, E. Den, Verdurmen, E.A.T.H., Verschure, R.H., 1979. Isotopic dating of older elements (including the Cabo Ortegal mafic-ultramafic complex) in the Hercynian Orogen of NW Spain: manifestations of a presumed Early Paleozoic Mantle-plume. Chemical Geology 24, 35-56.

Vernon, R.H., Clarke, G.L, 2008. Principles of metamorphic petrology. Cambridge University Press, New York.

Warren, C.J., Miller, J.M., 2007. Structural and stratigraphic controls on the origin and tectonic history of a subducted continental margin, Oman. Journal of Structural Geology 29, 541-558.

Warren, C.J., Waters, D.J., 2006. Oxidized eclogites and garnet-blueschists from Oman: $P-T$ path modeling in the NCFMASHO system. Journal of Metamorphic Geology 24 , $783-802$

Warren, C.J., Beaumont, C., Jamieson, R.A., 2008. Modelling tectonic styles and ultra-high pressure (UHP) rock exhumation during the transition from oceanic subduction to continental collision. Earth and Planetary Science Letters 267, 129-145.

Wei, C.-J., Powell, R., 2003. Phase relations in high-pressure metapelites in the system KFMASH $\left(\mathrm{K}_{2} \mathrm{O}-\mathrm{FeO}-\mathrm{MgO}-\mathrm{Al}_{2} \mathrm{O}_{3}-\mathrm{SiO}_{2}-\mathrm{H}_{2} \mathrm{O}\right)$ with application to natural rocks. Contributions to Mineralogy and Petrology 145, 301-315.

Wei, C-J., Song, S.-G., 2008. Chloritoid-glaucophane schist in the north Qilian orogen, NW China: phase equilibria and $P-T$ path from garnet zonation. Journal of Metamorphic Geology 26, 301-316.

Zuluaga, C.A., Stowell, H.H., Tinkham, D.K., 2005. The effect of zoned gamet on metapelite pseudosection topology and calculated metamorphic $P-T$ paths. American Mineralogist $90,1619-1628$ 